\title{
Los excesos del mono: salvajismo, transgresión y deshumanización en el pensamiento nahua del siglo XVI
}

Les excès du singe: sauvagerie, transgression et déshumanisation dans la pensée Nahua du XVI siècle

The excesses of the monkey: savagery, transgression and dehumanization in sixteenth century Nahua thought

Jaime Echeverría García

\section{(2) OpenEdition} Journals

Edición electrónica

URL: https://journals.openedition.org/jsa/14376

DOI: $10.4000 /$ jsa. 14376

ISSN: 1957-7842

\section{Editor}

Société des américanistes

\section{Edición impresa}

Fecha de publicación: 31 diciembre 2015

Paginación: 137-172

ISSN: 0037-9174

\section{Referencia electrónica}

Jaime Echeverría García, «Los excesos del mono: salvajismo, transgresión y deshumanización en el pensamiento nahua del siglo xvI», Journal de la Société des américanistes [En línea], 101-1 et 2 | 2015, Publicado el 15 marzo 2016, consultado el 24 febrero 2023. URL: http://journals.openedition.org/jsa/ 14376 ; DOI: https://doi.org/10.4000/jsa.14376 


\title{
Los excesos del mono: salvajismo, transgresión y deshumanización en el pensamiento nahua del siglo XVI
}

\author{
Jaime EcheverRía García *
}

\begin{abstract}
De los múltiples simbolismos que le fueron atribuidos al mono entre los antiguos nahuas, destacan los que tienen que ver con el exceso y la transgresión, de hecho, dichos simbolismos constituyeron en buena medida la esencia del mamífero. En el pensamiento nahua del siglo XVI, el comportamiento excesivo atentaba contra la identidad humana, de manera que conducía a una deshumanización simbólica. No obstante, en el mito realmente se efectuaba - la mayoría de las veces - una mutación animal. Además de estos simbolismos, el mono también representó el estado salvaje del hombre, que puede pensarse en dos direcciones: 1. como el estado de degradación del ser humano provocado por sus faltas; 2. como un estado salvaje primigenio por el que debe transitar todo hombre para poder alcanzar la cultura. [Palabras clave: nahuas, mono, salvajismo, exceso, transgresión, deshumanización.]
\end{abstract}

Les excès du singe : sauvagerie, transgression et déshumanisation dans la pensée Nahua du xvie siècle. Parmi les différents symbolismes qui ont été attribués au singe chez les anciens Nahuas, ceux qui ont à voir avec l'excès et la transgression se distinguent, dans la mesure où ces derniers caractérisent en grande partie l'essence de ce mammifère. Or, dans la pensée nahua du XVI ${ }^{\mathrm{e}}$ siècle, le comportement excessif attentait contre l'identité humaine, de sorte qu'il conduisait à une déshumanisation symbolique. Cependant, il est vrai que dans le mythe s'effectuait - la plupart des fois - une authentique mutation animale. Ainsi, en plus des symbolismes mentionnés, le singe a également représenté l'état sauvage de l'homme, lequel peut être conceptualisé selon deux axes différents : 1. comme l'état de dégradation de l'être humain, résultat des fautes que celui-ci a commises ; 2 . comme un état sauvage primaire par lequel tout homme doit passer pour pouvoir atteindre la culture. [Mots-clés : Nahuas, singe, sauvagerie, excès, transgression, déshumanisation.]

The excesses of the monkey: savagery, transgression and dehumanization in sixteenth century Nahua thought. Of the many symbolisms attributed to the monkey among the ancient Nahuas those related to excess and transgression stand out, as these qualities

* Universidad Nacional Autónoma de México, Circuito Mtro. Mario de la Cueva, Zona cultural, Ciudad Universitaria, México, D.F. [jecheverriagarcia@yahoo.com]. 
characterize for the most part the essence of this mammal. For the sixteenth century Nahuas, excessive behavior threatened the human identity, resulting in a symbolic dehumanization. Nonetheless, in mythical narratives, the mutation into an animal would usually actually happen. In addition to the symbolisms already mentioned, monkeys also represented the savage state of man, which can be understood in two ways: 1 . as the state of degeneration of a human being caused by his shortcomings; 2. as a primary savage state that every man must undergo in order to reach culture. [Key words: Nahuas, monkey, savagery, excess, transgression, dehumanization.]

Observar al mono era sumergirse en el pasado del ser humano, pero en un pasado remoto, imperfecto, caótico, un remedo del presente verdadero. $\mathrm{Su}$ inquietante semejanza con el hombre no hacía otra cosa que delatar el parentesco que existía con éste. Dijeron los informantes nahuas de Sahagún $(C F, \mathrm{XI}$, p. 14): « tiene manos humanas, pies humanos » (tlacamaie, tlacaicxe $)^{1}$; « su cara es un poco humana » (achi tlacaxayaque); " come como un ser humano » (huellacatlacua); « se sienta como un hombre »(moquichtlaliani) ${ }^{2}$. Según la antigua cosmovisión nahua, al ser destruido el Sol de Aire, Ehecatonatiuh, sus habitantes - o la mayoría de ellos - fueron convertidos en monos. Una fuente tardía afirma que dicha transformación fue motivada por las transgresiones de aquellos hombres (Veytia 2000, p. 43), lo que concuerda con uno de los elementos del complejo ideológico de creación y destrucción de eras cosmológicas: la falta.

El simio, entonces, fue visto como un ser humano bestializado. El cambio ontológico que implica el paso del hombre a un estado animal borra por completo los rasgos esenciales que definen la humanidad, que en gran medida están dados a partir de la prohibición y la contención de los impulsos. Los interdictos básicos sobre los que se erige la cultura radican en los contenidos de sexualidad y de muerte, tal como señaló Sigmund Freud (2000, p. 145). Justamente, el ser que se encuentra fuera de los límites de la cultura se ha despojado de dichas prohibiciones. El ser animalizado, en consecuencia, se distingue por un deseo sexual y de muerte irrefrenables, y esto se observa con claridad en las descripciones etnográficas del mono y de seres con rasgos simiescos. Volviendo otra vez con Freud (2003, p. 191-192), él comparó el inconsciente con el instinto animal. Aquél se forma precisamente de pulsiones sexuales y de muerte sobre las que se ha ejercido represión por considerarse atemorizantes, y que han devenido inconscientes como un mecanismo de defensa. Así, bajo un estado

1. La ortografía del náhuatl ha sido normalizada con base en el Gran Diccionario del Náhuatl $(G D N)$.

2. Existen dos especies de mono en el territorio mexicano: el araña (Ateles geoffroyi) y el saraguato o mono aullador (Allouata palliata). El mono araña es el que llamó la atención de los habitantes del Altiplano central, pues de las dos especies existentes, éste fue el único que se plasmó en los códices y en la escultura mexica. 
animal no existe conciencia, sólo aflora el instinto. No existe represión, pues ya ha quedado anulada. No hay vergüenza, pues ésta define al ser humano ${ }^{3}$.

Dentro de los múltiples valores que poseyó el mono entre los nahuas del siglo XVI, quiero destacar sus significados de transgresión y de exceso, que radican principalmente en el ámbito del sexo, y las consecuencias que acarreaba un comportamiento de tal naturaleza en el hombre: la deshumanización. En la lámina 32 del Códice Vaticano B (1972) (Figura 1, página siguiente) se ilustra una figura de simio que, mediante su actitud corporal y su acción, condensa aquellos significados. El mamífero está representado con la cabeza girada hacia atrás, los brazos levantados a la altura de los hombros con las manos abiertas, y expulsa un chorro de excremento que se dirige hacia la cabeza de una deidad de la muerte 4 .

La típica ambivalencia de sentido de la cosmovisión nahua igualmente se hace presente en la figura transgresora del mono, pues así como fue representado en los códices como un animal infractor - las fuentes documentales también lo dejan entrever -, algunos datos lo muestran desempeñando una función remediadora y punitiva.

La metodología que sigo en la elaboración del presente artículo es la conjunción de las fuentes históricas - tanto escritas como códices -, las etnográficas y el material arqueológico. De esta manera, se plantea un estudio interdisciplinario con el fin de ofrecer el cuadro más completo respecto a los simbolismos de transgresión y deshumanización del mono entre los antiguos nahuas.

3. Por cuestiones de espacio no me puedo extender en la exposición de las formulaciones freudianas sumariamente esbozadas, y no es mi objetivo hacerlo - para ello, remito al lector a los textos Tótem y tabú y Lo inconciente de Sigmund Freud que aparecen en la bibliografía. Aunque éstas tienen tintes universalistas, tampoco es mi intención empatarlas con el pensamiento nahua, pero sí sugerir su similitud con ciertos aspectos de dicho pensamiento, como la constitución de la cultura, y por ende, del ser humano, a partir de la norma, esto es, de la prohibición/represión; así como la asimilación del deseo inconsciente asocial e irresistible con el aspecto animal de la persona. En un texto inédito, Alessandro Lupo (en prensa) llega a semejantes planteamientos al analizar narraciones huaves sobre encuentros sexuales entre humanos y animales. Respecto del cuento de Xawealat - un joven que se come a su hermana, viola a la Luna y posteriormente es convertido en conejo por ésta -, dice Lupo, « representa en clave amerindia el eterno dilema de la relación entre el imperio de los instintos y la libertad de acción del sujeto, entre los ocultos e [...] [incontrolables] componentes ferinos del inconsciente humano y la necesidad del ser humano, para distinguirse de los animales y elevarse por encima de ellos, de someterse a una larga y fatigosa disciplina cuyo resultado es un equilibrio siempre frágil ». El antropólogo termina su texto afirmando que mediante la apropiación de los valores culturales y el dominio de los impulsos animales, la sociedad huave trata de hacer plenamente humanos a sus integrantes.

4. En el apartado « Transgresión y exceso sexual » explico cada uno de estos aspectos, los cuales son retomados más adelante en el apartado « Seductor, amante y raptor ». 


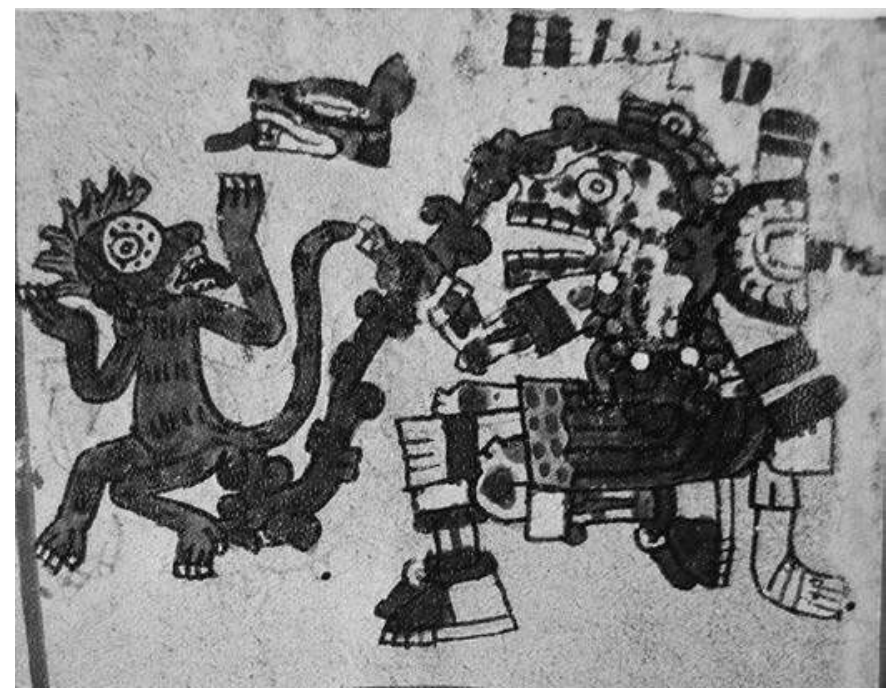

Fig. 1 - Ozomatli que defeca en la cabeza de Mictlantecuhtli (Códice Vaticano B 1972, lám. 32, detalle).

\section{La destrucción de los hombres por el viento}

Quiero comenzar con las diferentes versiones que narran la transformación de los hombres en monos durante la era Ehecatonatiuh, y resaltar algunos aspectos que considero de interés. Una serie de fuentes coinciden en afirmar que correspondió a la cuarta edad, cuyo signo fue nahui ehecatl, " cuatro viento » (Benavente 1996, p. 548; Anales de Cuauhtitlan 2011, p. 31; Histoyre du Mechique 2002, p. 145; Hernández 1986, p. 145). El dios que rigió esta era fue Quetzalcóatl (Historia de los mexicanos por sus pinturas ${ }^{5} 2002$, p. 35), lo que fácilmente se entiende al ser el dios del viento. Una segunda y más abundante serie de documentos ubican a Ehecatonatiuh como el segundo Sol (Leyenda de los Soles 2002, p. 175; HMP 2002, p. 35; Muñoz Camargo 1998, p. 164; Códice Vaticano A 1964, III, p. 23; Alva Ixtlilxochitl 1997, I, p. 264; Veytia 2000, p. 47-48). Mientras que en otro documento, Alva Ixtlilxochitl (1997, II, p. 7) sitúa a dicho Sol en la tercera edad ${ }^{6}$.

En general, todas las versiones confluyen al narrar los desastrosos efectos ocasionados por poderosas ráfagas de viento que terminaron por perder el mundo, y la mutación de los hombres en simios. En palabras de fray Toribio

5. A partir de aquí, $H M P$.

6. Respecto a la sucesión de los Soles, véanse Moreno de los Arcos (1967, p. 200) y Graulich (1990, p. 101, 296-298). 
de Benavente (Benavente 1996, p. 548): « Fue tan ympetuoso el ayre y viento que hizo, que todos los montes y árboles destruyó y arrancó, y leuantaua las grandes peñas y las quebrantaua y hazía yr rodando, y todos los hedificios destruyó. » Y señala el franciscano que los indios decían que los monos eran los hombres de la cuarta edad. Los Anales de Cuauhtitlan (2011, p. 31) precisan que los hombres transformados en aquellos mamíferos fueron hombres-mono (tlacaozomatin), a quienes se les arrojó al bosque.

Esta interesante mención puede identificarse con una escultura azteca en piedra del musée du quai Branly de París (Figura 2), que representa el cuerpo de un hombre sedente que viste maxtlatl - especie de calzoncillo -, pero, en oposición, está provisto de una cabeza y cola de simio. La primera se reconoce por el topete hirsuto, los grandes ojos circulares, la boca que parece soplar y el pelo que recubre gran parte del rostro; mientras que la cola sale del maxtlatl y sube por la espalda. Para Leonardo López Luján y Marie-France FauvetBerthelot (2005, p. 129, figura 52), esta estatua probablemente representa a Ehécatl-Quetzalcóatl o a XochipilliMacuilxóchitl. Yo, en cambio, considero que en esta imagen bien podemos ver reflejado a uno de los tlacaozomatin, es decir, el ser humano degradado a una condición simiesca ${ }^{7}$.

El descenso hacia el ámbito animal sufrido por la humanidad igualmente repercute en el espacio habitado, pues la nueva condición obliga el desplazamiento del hombre deshumanizado hacia el espacio salvaje. Y no sólo eso, la geografía condiciona la identidad humana o animal. En un mito popoluca (Foster 1945, p. 239), Cristo les

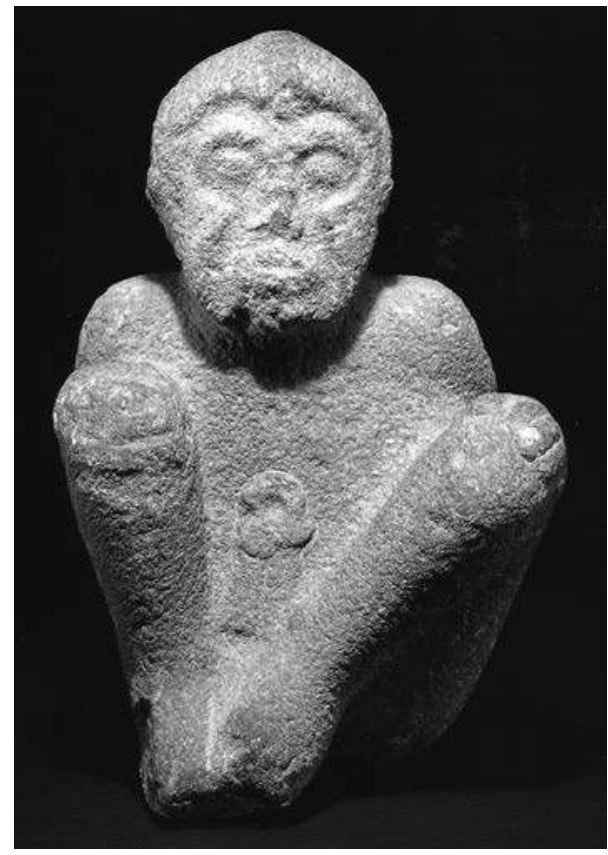

Fig. 2 - Hombre-mono, musée du quai Branly (López Luján y FauvetBerthelot 2005, p. 129, figura 52, cat. 52).

7. Sin negar que las ligas del mono con aquellas deidades fueron demasiado estrechas, no necesariamente cualquier escultura o figurilla con rasgos simiescos debe evocar a Ehécatl o a Xochipilli, a no ser que dichas imágenes estén adornadas con algunos de sus atributos iconográficos: orejeras epcololli y pectoral ehecailacacozcatl para la primera; y orejeras oyohualli para la segunda. Aunque el ozomatli portó los significados de aquellos dioses, el mamífero por sí mismo contó con un simbolismo particular, lo que no quiere decir que éste no fuera compartido con otros animales o divinidades. 
voltea la cabeza a los sobrevivientes del diluvio y los avienta a los árboles, y es en ese momento que se convierten en simios. De por sí, los hombres que habitaban el Sol de Aire poseían una condición más ligada a la naturaleza, lo que se refleja en el tipo de alimento que consumían. Según la Leyenda de los Soles (2002, p. 175), comían matlactlomome cohuatl, « doce serpiente »; mientras que la Histoyre du Mechique (2002, p. 145) apunta que « se alimentaban de un fruto que se da en un árbol llamado mizquitl »; y una tercera variante la encontramos en el Códice Vaticano A (1964, III, p. 23): « no comían salvo frutas silvestres que llamaban acotzintli ». Estos tres productos, de origen silvestre, contrastan con el maíz, una planta cultivada, el alimento prototípico del hombre verdadero. En este sentido, Michel Graulich (1990, p. 101, 296-298) propuso ordenar los Soles en un plano vertical con base en la idea de progreso, donde las creaciones son cada vez menos imperfectas y el alimento va de lo silvestre hasta llegar al producto cultivado, el maíz, alimento de la era presente.

La elección del mizquitl o mezquite como el alimento de los habitantes de Ehecatonatiuh pareciera no ser casualidad. Previo a su huida a Tlapallan, Quetzalcóatl convirtió los árboles de cacao en mezquites $(C F$, III, p. 33). El cacao es uno de los frutos favoritos del mono, y en el arte maya se le representa con frecuencia asociado a este producto (Nájera 2012). Por otro lado, dicho mamífero mantuvo estrechas ligas con Quetzalcóatl.

Respecto a la mutación de los hombres, algunas fuentes especifican que fueron arrastrados o levantados por el viento, y así se transformaron en monos. El autor de este gran ventarrón fue Tezcatlipoca (Leyenda de los Soles 2002, p. 175; HMP 2002, p. 35). Según Alva Ixtlilxochitl (1997, I, p. 264; también Veytia 2000, p. 43), muchos hombres y mujeres lograron escapar del gran huracán que arrasó con todo lo que había a su paso, refugiándose en cuevas y otros lugares lejos de su alcance. Pasados algunos días, salieron de su escondite y encontraron toda la tierra « cubierta y poblada de monos », animal que hasta entonces no conocían, declaró Mariano Veytia (2000, p. 43). En cuanto a la versión tlaxcalteca, los hombres fueron levantados del suelo por huracanes hasta perderse de vista, para luego caer y hacerse pedazos; mientras que las gentes que escaparon se « quedaron enredadas por algunas montañas y riscos escondidos, y que se convirtieron en monas y micos » (Muñoz Camargo 1998, p. 164). De nuevo se observa que el ámbito geográfico determina la naturaleza humana o animal, pues el refugio en sitios agrestes contribuyó a la mutación en simio. En este sentido, el hábitat es transformador.

No podemos pasar por alto las implicaciones inmorales que conlleva introducirse en el bosque o en otros lugares salvajes en el pensamiento nahua. Se decía que el joven que contrariaba el orden moral y el deseo de la divinidad se internaba en la barranca, en los peñascos, en el zacatal o en el bosque; se hacía conejo y venado, que eran los típicos animales del monte, y seguía su camino, el de la vagancia (García Quintana 1974, p. 157, 159). Las concepciones del 
bosque como un lugar de inmoralidad y alejamiento del dios, así como un espacio donde se adquiere una condición animal, ya señalado arriba, están expresadas en varios mitos chinantecos. Se narra que cuando apareció Cristo-Sol en el mundo, los hombres que no querían persignarse, ni ver la luz, ni oír la campana ni saber del cura, « se fueron al monte y se volvieron monos porque no les gustó vivir bajo la luz del cielo », o se metieron dentro de la tierra; mientras que los que permanecieron se hicieron cristianos. « Desde entonces tienen los changos las patas como manos y desde entonces no tienen vergüenza » (Weitlaner 1977, p. $218,224,226)$.

Habiendo adquirido forma simiesca, los hombres quedaron privados de razón y perdieron el habla, $\mathrm{y}$ « no les falta otra cosa sino la habla y quedaron mudos para ser hombres perfectos », apuntó Muñoz Camargo (1998, p. 164). Una información muy interesante y única en las descripciones de la destrucción del Sol de Aire, proporcionada por Mariano Veytia ${ }^{8}$, es que los hombres de esta edad « eran los ociosos y vagabundos que en castigo de su holgazanería fueron convertidos en monos ». Y a diferencia de Camargo, según los datos obtenidos por Veytia (2000, p. 43), « creían que sabían hablar, y que el no hacerlo era porque no los obligasen a trabajar ». Recordemos que en el Códice Vaticano $A$ (1964, III, p. 40) se le atribuye al simio la ociosidad.

En el Popol Vuh (2005, p. 29, 31-32) también encontramos datos de gran interés respecto a los hombres de una era anterior cuya descendencia fueron los monos. Después de la creación fallida de los hombres de lodo, los dioses crearon muñecos labrados en madera, quienes se parecían al hombre, hablaban como él y poblaron la Tierra. Aunque tuvieron descendencia, « no tenían alma, ni entendimiento, no se acordaban de su Creador, de su Formador, caminaban sin rumbo y andaban a gatas ». " Fue solamente un ensayo, un intento de hacer hombres. » La parte del cuerpo sobre la que sufrieron daño antes de ser destruidos por un diluvio tiene implicaciones importantes. Sus utensilios de trabajo y animales se rebelaron contra ellos por el mal trato que les habían dado: los perros les destrozaron las caras, así como los comales y las ollas; las piedras del hogar « se arrojaron directamente desde el fuego contra sus cabezas causándoles dolor »; " a todos les fueron destrozadas las bocas y las caras. Y dicen que la descendencia de aquéllos son los monos que existen ahora en los bosques; éstos son la muestra de aquéllos, porque sólo de palo fue hecha su carne por el Creador y el Formador $»$.

En la cabeza y el rostro se asienta la identidad humana, por lo que un golpe en esta parte del cuerpo implica su pérdida y la acción que facilita el tránsito hacia la bestialidad. Este atentado contra los hombres de madera, aunque su

8. Veytia es tan tardío como el siglo xVIII, mientras que la mayoría de las narraciones de la destrucción de los Soles corresponden al siglo Xvi. Esto obliga a que tomemos con reserva los datos proporcionados por el historiador novohispano, pero no por ello que los desechemos. 
destrucción se haya llevado a cabo por un diluvio, posiblemente condujo a su descendencia a una humanidad disminuida, encarnada en la figura del simio. Por otro lado, el material con el que fueron creados dichos hombres en el mito maya quiché podría mantener concordancia con el nombre en náhuatl asignado al mono además de ozomatli: cuauhchimal (CF, XI, p. 14; Molina 2004, fol. 86r), " escudo de madera ». Posiblemente este apelativo alude tanto a un rasgo físico como al hábitat del mamífero. Dijeron los informantes de Sahagún $(C F, \mathrm{XI}$, p. 14) que la espalda del simio es redonda, lo cual remitiría a la forma circular del escudo"; mientras que la madera apunta al bosque, el espacio habitado por aquél. Además de la descripción de los hombres de madera más ligada al ámbito animal - no tenían alma ni entendimiento, caminaban a gatas -, el material con que fueron creados enfatiza el espacio salvaje y ausente de la presencia humana.

\section{De mono-chichimeca a la adultez civilizada}

En este apartado quiero sustentar la hipótesis de que en el desarrollo del individuo, desde su nacimiento hasta la vida adulta, se reproduce el proceso mítico del desarrollo del grupo humano desde unos orígenes salvajes hasta alcanzar la civilización por obra de los españoles y el cristianismo, en el caso indígena contemporáneo, o desde un estado chichimeca a uno tolteca, en tiempos prehispánicos ${ }^{10}$. Dicho planteamiento tiene un parangón con la « ley fundamental de la sociogénesis » propuesta por Norbert Elias (2009, p. 75), que reza que « durante su vida el individuo vuelve a recorrer los procesos que ha recorrido su sociedad a lo largo de la suya $»^{11}$.

La anterior hipótesis se basa en parte en el modelo del proceso de creación de los grupos humanos planteado por Alfredo López Austin y Leonardo López Luján (1999, p. 51-55, 65, 68, 71), que expongo de manera muy sucinta. En el

9. El término cuitlaololtic « el que tiene la espalda redonda » no sólo describió al simio $(C F$, XI, p. 14), sino que también refirió a las aves tlalalacatl, un tipo de ganso ( $C F, \mathrm{XI}, \mathrm{p} .27)$; atzitzicuilotl, el falaropo; aztatl, la garza ( $C F$, XI, p. 28) y el tecolotl, tecolote ( $C F$, XI, p. 42).

10. Quiero hacer una advertencia. La visión que planteo del chichimeca, en la cual se exaltan sus características de rusticidad e incivilización, está dominada por el mito y el imaginario, pero no es la única. Desde una postura histórica, la identidad chichimeca se funde con la tolteca para dar origen a los diferentes altepetl del Valle de México (Navarrete Linares 2011a, p. 259-341, 2011b).

11. El planteamiento general de El proceso de la civilización de Norbert Elias (2009), es que las transformaciones en las estructuras de personalidad (psicogénesis) mantienen sintonía con los cambios estructurales de la sociedad (sociogénesis); dichos cambios son de larga duración. Estas constituciones sociogenéticas y psicogenéticas son paralelas a la constitución biogenética. En este punto, Elias se apoya de forma implícita en la ley biogenética de Ernst Haeckel, que enuncia que la ontogénesis - el desarrollo biológico del individuo - recapitula la filogénesis - la evolución de la especie. La propuesta del sociólogo alemán está ubicada en el contexto medieval europeo y sus transformaciones hacia el Renacimiento. 
origen, los pueblos esperan en Chicomóztoc, que se asemeja a la vida intrauterina; posteriormente ocurre su salida de las siete cuevas, que guarda similitud con el momento del parto. Los grupos humanos mantienen unos inicios chichimecas, cuyo tránsito hacia un estado tolteca involucra un proceso civilizatorio mítico que finaliza con la posesión definitiva de la tierra. Este tiempo, según los autores, corresponde al inicio de la vida.

Ciertos datos lingüísticos e históricos me hacen pensar que lo chichimeca representa la infancia, y por consiguiente, lo tolteca corresponde a la adultez (véase Davies 1977, p. 160). Por otro lado, en varias cosmovisiones indígenas actuales, tanto el feto como el recién nacido son concebidos como seres de naturaleza animal, de tal suerte que son llamados monos. Con el rito del bautismo, dicha condición muda al conferirles humanidad. Este cambio ontológico igualmente determina la adquisición de un estado de calor, anteriormente inexistente por dominar el frío. El cruce de informaciones permite trazar vínculos entre lo chichimeca y el mono, que se sustentan en las ideas de lo primigenio, del salvajismo y de la anticultura. A continuación expongo el desarrollo del planteamiento.

Un relato teenek (huasteco) sobre sus orígenes presentado por Anath Ariel de Vidas (2003, p. 410-411) facilita establecer dicha articulación. En él, la descripción denigrante de los antiguos teenek sorprende al ser tan semejante a la caracterización que hicieron del chichimeca las fuentes históricas del siglo XVI. Cito la información de Ariel de Vidas:

Los ancianos nos dijeron que antes los teenek vivían en una cueva, en el cerro, en el monte. No sabían lo que era una casa, no conocían la lumbre [...], comían raíces de árboles, frutas, todo crudo. Cuando llegaron los conquistadores y los hallaron, los teenek empezaron a conocer la luz, la ropa. Antes, eran monos, no tenían casas. Hacían un gran hoyo en la tierra [...]. Allí tenían a sus hijos e hijas [...]. El sol no siempre había existido, sólo había agua y la comida se comía cruda. Los monos hablan teenek [...]. Los huastecos andaban desnudos, no estaban bautizados [...]. No tenían casas, andaban como venados, como conejos [...]. Andaban desnudos, vivían en cuevas, debajo de las piedras, en zanjas. Los españoles les enseñaron a hablar, los bautizaron, les dijeron cómo se come.

Podemos extraer de este relato los rasgos típicos que conformaron la representación nahua posclásica del chichimeca, así como algunas de sus connotaciones simbólicas: creación del ser humano en cuevas y habitación en ellas, desconocimiento del fuego, alimentación a base de productos silvestres y carne cruda, desnudez, práctica de cavar hoyos en la tierra, ausencia del sol, y andar como venados y conejos ${ }^{12}$.

12. Véanse, por ejemplo, Benavente 2007, p. 213; Mendieta 2002, p. 268; Durán 2002, I, p. 65; Sahagún 2002, II, p. 957; Anales de Cuauhtitlan 2011, p. 27, 29; Relación de Michoacán 1989, p. 180; Alva Ixtlilxochitl 1997, I, p. 289; Histoyre du Mechique 2002, p. 127; Ramos de Cárdenas 1987, p. 242. 
De los anteriores elementos sólo voy a destacar aquéllos que, por su singularidad, apuntan sin lugar a dudas a lo chichimeca. Primero, cuando Icxicohuatl y Quetzaltehueyac llegan a Culhuacatepec para solicitar la ayuda de los chichimecas, la Historia Tolteca-Chichimeca ${ }^{13}$ (1989, fol. 17r, p. 163-164; fol. 18r, p. 166-167) los llama xicotli y pepeyoli, que eran los nombres de dos tipos de abejas que, según los nahuas, se caracterizaban por hacer cuevas en la tierra para fabricar su miel (Sahagún 2002, III, p. 1052). De ahí su parentesco con los chichimecas. Segundo, el periodo de migración se relaciona con la oscuridad, es decir, con la ausencia del sol: « De los años en que los chichimecas venían caminando se dice: "todavía era de noche" » (Anales de Cuauhtitlan 2011, p. 29). Y tercero, el conejo y el venado fueron los típicos animales del monte vinculados con la actividad errante chichimeca. « Seguir el camino del conejo y del venado » fue un difrasismo que significó la vagancia, y el comportamiento inmoral en general. Seguir el camino de las bestias del monte era, de alguna manera, señala Louise Burkhart (1986, p. 113), seguir el « camino de los ancestros », pero los ancestros chichimecas incivilizados, más que aquéllos más inmediatos que eran los modelos del comportamiento correcto.

La actitud civilizadora del español frente a los monos-teenek del relato anterior igualmente se asemeja a la del tolteca frente al chichimeca. Así como «los españoles les enseñaron a hablar », « les dijeron cómo se come », al aceptar abandonar los chichimecas su vida cavernícola y serrana, el ya mencionado Icxicohuatl les dio a comer maíz e inmediatamente empezaron a hablar náhuatl (HTCH 1989, fol. 18v, p. 167; fol. 19v, p. 169). Asimismo, en el Códice Tlotzin se narra cómo este chichimeca comió por primera vez carne asada - pues la comía cruda - y alimentos preparados a base de maíz - tamales y atole - por intervención del chalca Tecpoyo Achcauhtli, quien también le enseñó a hablar náhuatl (León-Portilla 1967, p. 72). El maíz y la lengua náhuatl fueron considerados marcadores de civilización.

En el contexto del enfrentamiento de dos modelos culturales disímbolos y del dominio de uno sobre el otro, la historia antigua teenek es borrada y vuelta a escribir, pues se ve la necesidad de establecer unos orígenes salvajes para explicar la sujeción española (véase Ariel de Vidas 2003, p. 413), incluso, justificarla. Y más que una reescritura de la historia, hay una reactualización del antiguo discurso histórico indígena. Se recurre a un modelo mítico-histórico mesoamericano del desarrollo de los pueblos, con la diferencia de que los nuevos detentadores de la cultura son de una naturaleza totalmente extraña, pero no por ello se les deja de insertar en el discurso indígena desempeñando un papel tolteca, esto es, civilizador. Sólo a través de la chichimequización o la conversión en mono, es decir, sólo a través de la salvajización, es posible explicar la adopción de la civilización y de la fe cristiana, simbolizada por el bautismo, cuya implicación

13. A partir de aquí, $H T C H$. 
es de gran envergadura: la recuperación de la humanidad. La sustitución de la figura del chichimeca por la del mono se entiende porque ambos encarnan, además de lo primigenio, la contradicción del orden humano. Otra explicación es que son seres intermedios entre la naturaleza y la cultura, que, mediante un proceso civilizatorio, tienen la posibilidad de adquirir una plena condición humana.

En tiempos del gobierno de Tlotzin, la gente que no quería practicar la agricultura y deseaba persistir en las costumbres chichimecas huyó a las sierras de Metztitlan y Totepec (Alva Ixtlilxochitl 1997, II, p. 26). Y ya en tiempos coloniales, los grupos indígenas considerados chichimecas mantuvieron una actitud reacia a la dominación española, hecho que provocó la intensificación de su estereotipo salvaje (véanse por ejemplo Ramos de Cárdenas 1987, p. 224225; Muñoz Camargo 1998, p. 86). La rebeldía chichimeca es paralela a uno de los significados del mono en los mitos indígenas: ser el hombre del pasado que rechaza a Cristo - rechazo a ser evangelizado y a integrarse al orden colonial - y huye de él al internarse en el bosque y sumergirse en la tierra (por ejemplo Weitlaner 1977, p. 218; Ariel de Vidas 2003, p. 216). En ambos casos, la rebeldía se traduce en un rechazo a la cultura dominante.

Ahora bien, al principio del apartado se sugirió la idea de que el desarrollo del hombre es análogo al desarrollo del grupo humano. En ambos se parte de un origen bestial o muy ligado a la naturaleza, asimilado con la infancia, para posteriormente alcanzar el estado humano y ordenado, típico de la vida adulta. Este tránsito, que también implica un paso de lo frío a lo caliente, sólo es posible mediante la intervención de marcadores de civilización, que se encuentran en sintonía con el ideal del ser humano.

Algunos grupos mayas como los tzotziles y los mochós conciben al nonato y al bebé no bautizado como monos. Esta categoría animal es superada una vez que el pequeño ha sido bautizado y ya cuenta con padrino y madrina (Bricker 1986, p. 152; Gossen 1989, p. 60; Petrich 1985, p. 232). Entre los tzotziles de Chamula, « el ciclo vital es concebido como un ciclo de aumento de calor desde un comienzo frío ». Dicha calidad fría del infante se ve reflejada precisamente en el término maš, « mono », pero con el bautismo, y posteriormente la madurez sexual, va adquiriendo un calor en constante aumento que alcanza un alto nivel con el matrimonio y la reproducción, que expresan madurez social (Gossen 1989, p. 60). A esta información podemos agregar uno de los nombres de los gigantes que antecedieron a la raza humana según los teenek de San Luis Potosí, Mut'in, cuya traducción literal es « aquellos cuyo desarrollo se detuvo en el nivel del mono » (Ariel de Vidas 2003, p. 219).

Me remito nuevamente al chichimeca. Hace algunas décadas, Nigel Davies (1977, p. 160) ya había sugerido que los chichimecas eran los jóvenes o nuevas gentes, y los tolteca-chichimecas implicaban unas gentes que ya se habían vuelto mayores o más civilizadas. Para el investigador, el nombre chichimeca deriva de su lugar de origen Chichimani, que significaría « chupadero », « lugar de los recién 
nacidos », o « lugar de los jóvenes », lo que considero acertado. Sin embargo, en estricto sentido, el topónimo debería ser Chichiman, pues los gentilicios que acaban en - mecatl como chalmecatl o chichimecatl les corresponde el locativo man, pero éste nunca aparece en las fuentes históricas (Reyes y Odena 2001, p. 254). Con base en el registro de las vocales largas del gentilicio chichimecatl (chīchìmécatl) asentado por Horacio Carocci (1983, p. 4) en su Arte de la Lengua mexicana, Leopoldo Valiñas (comunicación personal, marzo de 2007) propone su traducción como « habitante del lugar donde los senos se extienden ${ }^{14}$.

Esta traducción recuerda la morada celeste a la que se dirigían los niños que morían en la etapa de lactancia, el Chichihualcuahuitl, « árbol de senos », ilustrada en el Códice Vaticano A (1964, III, p. 17) como un lugar en el que se encuentra un árbol con frutos en forma de senos, de los cuales maman niños. Al ser lactantes, fenecieron sin haber probado maíz (véase Fernández de Oviedo 1944-1945, XI, p. 73).

Debido a su vínculo con el seno y, por ende, con la leche materna y el amamantamiento, así como su caracterización como seres que no consumían maíz, los chichimecas debieron identificarse con los lactantes. Una vez que el niño ingería maíz, adquiría una condición que lo alejaba de un estado primigenio salvaje chichimeca, y que lo insertaba por completo en el ámbito de la cultura, asimilado con lo tolteca, así, su humanización se veía completada. Como la ingesta del maíz es inherente a la lengua náhuatl, su correcto aprendizaje debió ser otro elemento que determinaba el distanciamiento del origen chichimeca y la rotulación de humanidad. En Amatlán de los Reyes, Veracruz, al balbuceo de los niños se le llama popolotza (Kirchhoff, Reyes y Güemes en HTCH 1989, p. 169, nota 4). Este término se relaciona con el verbo popoloca, del que Molina da la definición de « hablar lenguaje barbaro », « hablar entre dientes » (Molina 2004, fol. 67v). También es el nombre genérico de la lengua que hablaban los chichimecas, que correspondió al pame, al mazahua o al otomí (León-Portilla 1967, p. 67, 71) ${ }^{15}$.

A la luz de la información etnográfica, se hace evidente la estrecha relación simbólica que guarda el consumo del maíz con el ritual del bautismo: ambos son actos necesarios que humanizan al infante. Esperanza Penagos (2000, p. 5-6) sugiere que los mazatecos consideran al niño que no ha sido bautizado y que no ha comido maíz como un ser de « incompleta humanidad », que puede observarse en el rito que sigue a la muerte de un individuo de pocos días o meses de edad. Antaño, los niños que morían sin ser bautizados eran enterrados en un espacio no socializado por la presencia ni la actividad humanas, en el monte

14. Aunque el locativo -man (que significa extendido) no aparece en las fuentes, como se acaba de señalar, Valiñas lo toma en cuenta para su traducción. Los otros elementos que la conforman son chichihualli « seno » y el absolutivo - $t$, que identifica el gentilicio.

15. La lengua que originalmente poseían los chichimecas de Xólotl era una popoloca, y fue Techotlalatzin, abuelo de Nezahualcóyotl, el primero que habló náhuatl (Chimalpain 1997, p. 67). 
alto. Mientras que en la actualidad, se suprimen muchos rituales mortuorios con los niños que murieron sin haber probado maíz, lo que simboliza su aspecto bestial. Estos niños mazatecos se dirigen al yia chiquí, « árbol de senos ».

En resumen, así como todos los grupos humanos transitaron de un estado chichimeca, asimilado con la infancia y el salvajismo, hacia uno tolteca, identificado con la etapa de madurez y la civilización, cada ser humano iniciaba igualmente su vida bajo una condición chichimeca, no enteramente humana, que se transformaba con el consumo del maíz y el aprendizaje de la lengua náhuatl. Estos marcadores de civilización lo dotaban de una completa humanidad, mientras la identidad social acababa de forjarse con la llegada de la edad adulta y la conformación de la familia. En el contexto indígena de hoy, debido a los antecedentes históricos de la sujeción colonial, los antepasados - pero los remotos - son concebidos como seres bestiales, cuya humanización sólo fue posible gracias a la aceptación del orden español y del cristianismo. A nivel individual, todo hombre recorre dicho proceso en su persona. Comienza siendo un mono desde que está en el útero hasta que recibe el bautismo, acto ritual, y también marcador de civilización, que modifica su naturaleza y lo posiciona en el ámbito humano.

\section{Transgresión y exceso sexual}

Aunque el destino que pronosticaban los signos de día ozomatli, es decir del día mono, era bastante favorable, el comportamiento inmoral de la persona que nacía bajo su auspicio lo trastornaba, pues al mostrar una actitud irreverente hacia su signo, aquélla provocaba su cólera que se materializaba en desgracias y enfermedades, como ocurría con todos los signos de los días del tonalpohualli. El carácter de algunas de las desdichas nos demuestra el significado transgresor del mono, específicamente en el terreno de la sexualidad. A diferencia del Códice Florentino, los Primeros Memoriales (Sahagún 1997, fol. 296r) precisan que si la persona - se señala al varón noble - no estimaba su signo ce ozomatli, éste la hacía enfermar de lepra, le causaba ceguera o alguna dolencia de la ingle; además, le ocasionaba vivir en la miseria y padecer hambre. Pero si la persona vivía con miedo de su signo sería rica y próspera. En cambio, el destino que le deparaba a la mujer noble que no respetara su tonalli de carga " uno mono » era la vida licenciosa (ahauilnemia) y el desamparo. Fray Diego Durán (2002, II, p. 236) consigna información muy similar: la mujer que naciera en el signo ozomatli sería « cantora regocijada graciosa no muy honesta ni casta risueña y muy fácil de persuadir en cualquier cosa $\gg{ }^{16}$.

16. Tal como ya lo había indicado Eduard Seler (1980, I, p. 102), la carga del signo xochitl « flor » era análoga a la de ozomatli. El noble que nacía bajo el signo ce xochitl sería cantor, portador de alegría, narrador de historias y artesano; pero si despreciaba su signo, a semejanza de ce ozomatli era castigado con lepra, ceguera y malestar en la ingle. Y la misma suerte corría el macehual. En el caso de la mujer, sería buena bordadora. Pero si no era devota a su signo padecería todo tipo de enfermedades y se volvería ahuiani (Sahagún, Primeros 
Al ser Xochipilli el regente del signo de día ozomatli (por ejemplo Códice Borgia 2008, lám. 13) (Figura 3), en el mono se proyectaron su identidad y ámbitos de acción, de tal manera que el exceso sexual del simio fue en cierta manera un reflejo de aquella deidad. Para Seler (1980, I, p. 102, 106), de las concepciones de Xochipilli como dios de la danza, de la música y del juego, y dios de los alimentos y la generación, resulta una tercera que se revela en la naturaleza del signo mono: la de un numen del placer, pero del placer transgresor. En estricto sentido, Xochipilli y Macuilxóchitl correspondieron a nombres de dos dioses diferentes, pero la cercanía de sus identidades llegó a concentrarlos en una sola (Sahagún 2002, I, p. 90). El aspecto transgresor de estas divinidades es más evidente en Macuilxóchitl, pues resalta desde su nombre e iconografía. El numeral cinco, macuilli, que conforma a aquél, y que también se plasmó en su pintura facial al estar indicada por una mano extendida sobre la mejilla y la boca $\left(C F, \mathrm{I}\right.$, p. 32), señaló el símbolo del exceso ${ }^{17}$.

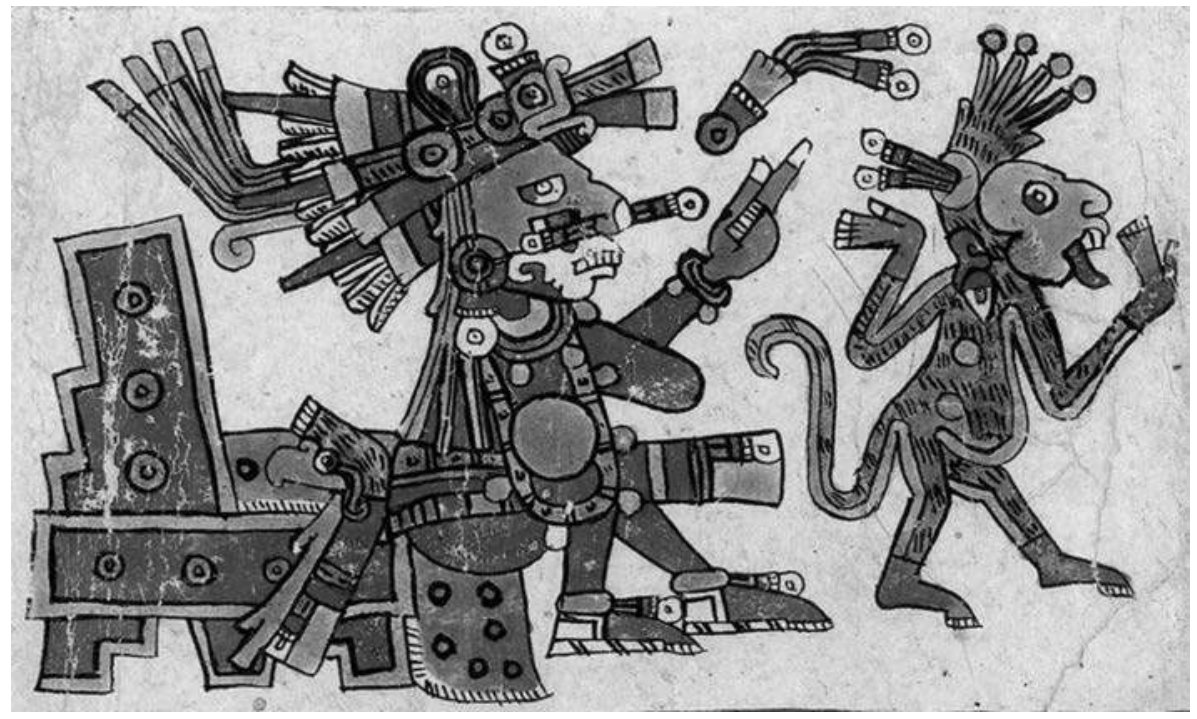

Fig. 3 - Xochipilli, dios patrono del signo ozomatli, onceavo del tonalpohualli (Códice Borgia 2008, lám. 13, detalle. Digitalización:

Biblioteca Rafael García Granados, IIH, UnAm).

Memoriales 1997, fol. 290v; CF, IV, p. 23, 25). La estrecha proximidad, casi fusión, entre los signos de día mono y flor, se explica a partir de las semejanzas de los dioses que regían dichos signos: Xochipilli-Macuilxóchitl y Xochiquétzal. Ambos presidían el deseo sexual - generalmente inclinado hacia el ámbito transgresor -, las flores, la fiesta y el placer en general, entre otros aspectos. De esta manera, Xochiquétzal fue la contraparte femenina de Xochipilli-Macuilxóchitl (Nicholson 1975, p. 421).

17. En el apartado « Exceso y deshumanización » se profundiza en la esencia del número cinco y sus repercusiones. 
Los códices refuerzan y amplían el simbolismo del mono que venimos tratando. La actitud corporal que generalmente ejecuta el simio en su representación - tanto en la pictografía como en el material arqueológico - son los brazos levantados a la altura de los hombros con las manos abiertas, y en ocasiones el torcimiento de la cabeza. Dicho torcimiento, algunas veces también del cuerpo, caracteriza, por ejemplo, a la diosa Ixnextli (Códice Telleriano-Remensis ${ }^{18} 1995$, fol. 11r) (Figura 4, página siguiente); a una deidad femenina en el Códice Borgia (2008, lám. 60) (Figura 5, página siguiente); y a un personaje masculino en el mismo códice (lám. 59), identificado como tlamacazqui (sacerdote), que aparece entre dos figuras de Xochiquétzal (Figura 6, página siguiente). Por su parte, el torcimiento de la cabeza del mono se ilustra en el Códice Vaticano B (1972, lám. 32) (véase Figura 1).

Pablo Escalante (2010, p. 332-333) ha identificado el gesto corporal comentado con el gozo. Y si nos remitimos a las identidades de los anteriores personajes, a su acción y a sus atributos iconográficos, se puede determinar que el gozo es de carácter sexual (Escalante 2010, p. 333) con una fuerte inclinación hacia lo transgresor. Ixnextli es una de las diosas que transgredió en Tamoanchan (CTR 1964, I, p. 191), y el glifo de excremento (cuitlatl) que porta en una de sus manos en el Telleriano-Remensis refuerza su condición contraventora. La esquina superior izquierda de la lámina 59 del Borgia, según la interpretación de Eduard Seler (1980, II, p. 167-168) (véase Figura 6, página siguiente), representa a un sacerdote que desvía su atención sexual hacia una prostituta - quien también tiene la cabeza torcida -, lo cual se insinúa a través de una caricia que aquél le hace en un seno. Por último, la imagen del simio arriba señalada - a la que se hizo referencia al inicio del artículo - tiene la particularidad de estar expulsando un chorro de excremento, símbolo de la impureza - marcadamente sexual -, el cual se dirige hacia la cabeza de una figura de Mictlantecuhtli.

Cecelia Klein (2001, p. 208) ha afirmado que los cuerpos, extremidades y cabezas volteados o contorsionados, especificaron con frecuencia en los códices la conducta sexual desordenada. Y en relación a las figuras del sacerdote y la prostituta, Klein (2001, p. 209) apunta que la desorientación de sus cuerpos expresa los principios de desorden moral y la falta de dirección que fueron atribuidos por los nahuas a los adúlteros. A partir de las estrechas similitudes que guarda la figura del mono referida con los otros personajes, podemos concluir que el torcimiento corporal no sólo expresó la condición sexual transgresora en el ámbito humano y en el divino, sino también en el animal. En la imagen aludida del Vaticano B se plasmó una doble marca de la naturaleza desenfrenada e inmoral del mono: el torcimiento de la cabeza y el excremento. A esta última podemos agregar el diseño del mechón del mono de las láminas 1 y 5 del Códice Vaticano B (1972) (Figura 7, páginas siguientes), que, en opinión de Seler (2004, p. 22), está dibujado como

18. A partir de aquí, CTR. 


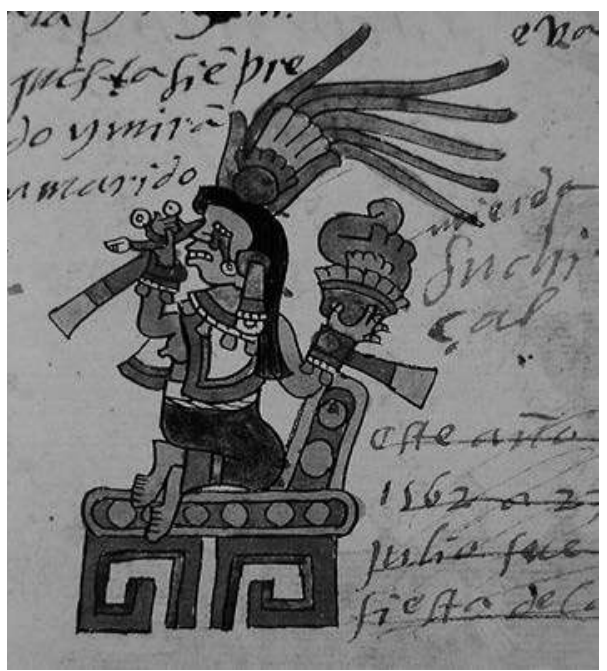

Fig. 5 - Deidad femenina (Códice Borgia 2008, lám. 60, detalle. Digitalización: Biblioteca Rafael García Granados, IIH, UnAm).
Fig. 4 - Ixnextli con el glifo de excremento en una mano (CTR 1995, fol. 11r, detalle).
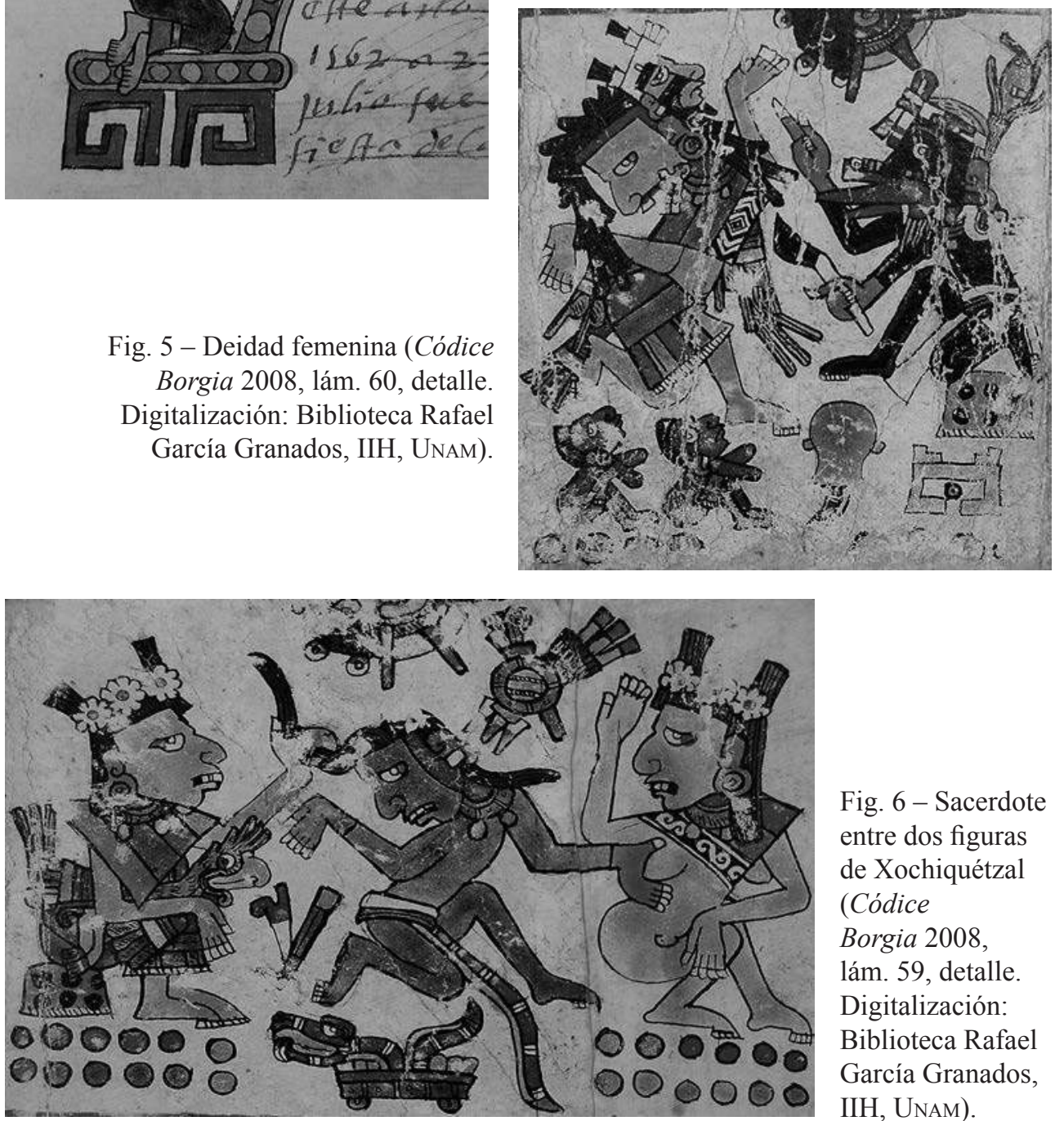

Fig. 6 - Sacerdote entre dos figuras de Xochiquétzal (Códice Borgia 2008, lám. 59, detalle. Digitalización: Biblioteca Rafael García Granados, IIH, UNAM). 


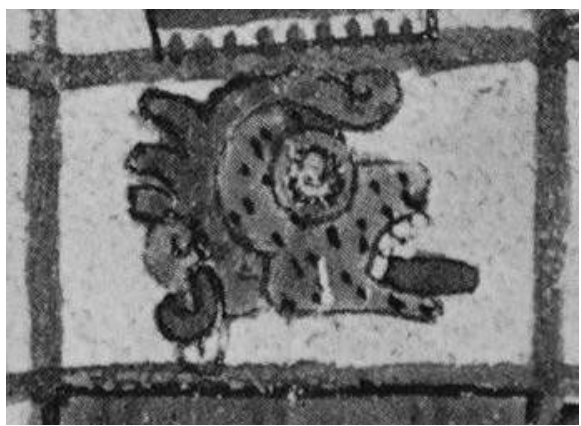

Fig. 7 - Rostros de mono con mechón que semeja el glifo de cuitlatl (Códice Vaticano B 1972, láms. 1, 5, detalle).
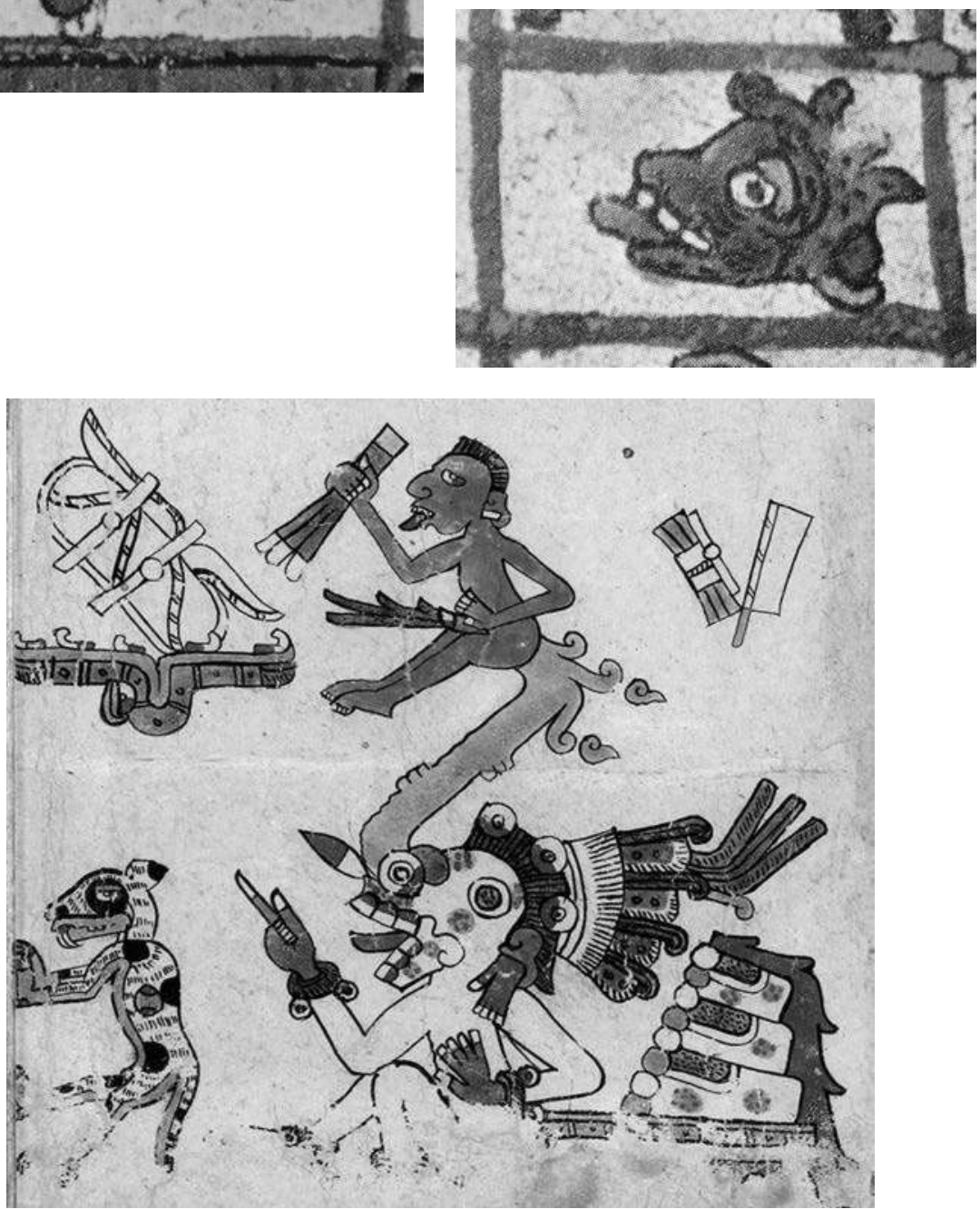

Fig. 8 - Transgresor con la lengua de fuera del décimo signo de los días (Códice Borgia 2008, lám. 13, detalle. Digitalización: Biblioteca Rafael García Granados, IIH, UnAm). 
cuitlatl (excremento), pintado de amarillo. Posiblemente, una tercera marca se indica en la representación de la lengua de fuera del mamífero, que se asemeja a la ilustración del transgresor del décimo signo de los días del Códice Borgia (2008, lám. 13) (Figura 8, página precedente), quien expele excremento y orina, porta un manojo de malinalli, o yerbas, y saca la lengua. El hecho de que este último rasgo sea un elemento común de representación del ozomatli, de igual manera que la postura comentada arriba de brazos levantados a la altura de los hombros con las manos abiertas, sugiere la idea de que la esencia del mono radicaba en el gozo, y, a la vez, de que la actitud o el estado gozoso fácilmente podía tomar un cariz transgresor al rebasar los límites de la moderación y ubicarse en el terreno del exceso. Así, el simio simbolizaba el gozo desmesurado. En palabras de Seler (1980, I, p. 102): « como animal del placer el mono es asimismo el animal de la voluptuosidad, de la concupiscencia, del amor sexual, del deseo pecaminoso y del pecado en general ».

La representación del mono con la inmundicia, por un lado, y su asociación con la deidad de la muerte, por el otro, nos lleva con facilidad a pensar que las transgresiones conducían a la muerte, o como lo he expresado en un trabajo anterior (Echeverría en prensa): que « el exceso aceleraba la consumación de la vida » (véase Seler 1980, I, p. 101). Aún más, la propia iconografía del ozomatli parece indicar su liga estrecha con la muerte. El pelaje de aquél se representó mediante malinalli, que era el « símbolo de la muerte rápida » (Seler 1980, I, p. 102; véase $C F, I V$, p. 55). Incluso, la manera particular de representar el rostro del mono en piedra con sus ojos hundidos sugiere la idea de una calavera, según comentó Seler (1980, I, p. 102). Afirma: « En las esculturas de piedra a veces no puede aclararse si se trata de una cabeza de mono o de un cráneo de muerto ».

Bajo una lógica donde los opuestos no son excluyentes sino complementarios, a la vez que el mono y Xochipilli-Macuilxóchitl encarnaban el desenfreno sexual y lo promovían, igualmente ejercieron una actividad punitiva y remediadora de sus consecuencias. Esta deidad castigaba con enfermedades en los genitales a las personas que habían quebrantado, por medio del acto sexual, el ayuno preparativo para su fiesta. Se decía que « hacen morir su ayuno por causa del tlazolli » (quintlazolmictia, in inezahualiz) (CF, I, p. 31). Señala Sahagún (2002, I, p. 90): « y este dios se ofendía mucho desto, y por esto hería con enfermedades de las partes secretas a los que tal hacía, como son almorranas, pudredumbre del miembro secreto $\gg$. Por otro lado, entre los antiguos nahuas, el consumo de la carne y los huesos de mono, tostados y molidos, aliviaban los dolores provocados por el « contagio gálico » o « mal francés », esto es, la sífilis, mediante la sudoración (Hernández 1959, III, p. 306; Ximénez 2001, p. 284). Entre nahuas y popolucas del Istmo veracruzano, la carne del mono sirve al mismo propósito (Münch 1994, p. 224).

Para Martha Ilia Nájera Coronado (2000, p. 54; 2008, p. 67; 2012, p. 165), los diversos significados atribuidos al simio responden a situaciones históricas 
precisas. En ellos pueden diferenciarse dos grupos de acuerdo al contexto cultural que nos refiramos. La visión indígena, que corresponde al pensamiento netamente prehispánico y que persistió entrado el periodo colonial, enfatizó la concepción del mono como « seres preculturales, intermedios, salvajes, sin facultad de hablar ni de pensar ». Durante la Colonia, las connotaciones simbólicas del mamífero fueron peyorativas. Se identificó por su aspecto - especialmente la cola - con el diablo y el pecado, también con la lujuria, el desorden y el infierno. Siguiendo la tradición medieval, « el mono simboliza las bajas pasiones humanas y los pecados, se manifiesta como quien parodia las acciones humanas, representa a la lujuria del hombre en estado de degeneración ». " Simboliza todo lo contrario a la conducta de templanza que buscaba inspirar el cristianismo. » No obstante, señala Nájera, los variados significados del simio reflejan en el fondo sus características, de tal manera que persiste su simbolismo original.

Quisiera hacer algunas precisiones a las anteriores aseveraciones. Tanto la visión del mono como un ser precultural y salvaje, como su concepción transgresora y lúbrica, formaron parte del simbolismo general del mamífero en el pensamiento indígena precolombino, $\mathrm{y}$, en el pensamiento nahua, en particular, pero dependiendo del contexto de su aparición, se hizo mayor énfasis en un significado que en otros. Cuando las fuentes históricas narran la destrucción del mundo por el viento, se acentúa la condición pre-humana y salvaje del simio; mientras que los códices subrayan el ámbito lúdico, del placer y de la transgresión (sexual) del simio, a partir de sus atributos iconográficos, tal como se acaba de exponer. Y si nos remitimos al contexto maya nos vamos a encontrar con asociaciones semejantes del mono. Según afirman Mary Miller y Karl Taube (1993, p. 118), el mono araña frecuentemente personifica en el arte del Clásico maya el comportamiento licencioso y el abandono sexual. En el mismo sentido, Stephen Houston (2001, p. 215) afirma que, opuesto a los ideales mayas clásicos de la inexpresión de la emoción y el auto-control, el simio simbolizó la inmoderación y la animalización de las conductas y las emociones, que se observa en las escenas simiescas de coito (véase Figura 9, página siguiente). Más allá de pensar la concepción inmoral y lasciva del mono como una influencia occidental, debemos de pensar en paralelismos en los significados del simio entre el Viejo y el Nuevo Mundo.

Por otro lado, sin negar que el simbolismo diabólico del mono fue introducido por el pensamiento medieval en América, y que a la fecha sigue persistiendo entre los indígenas la asociación del demonio con el simio (Bricker 1986, p. 75, 143; Gossen 1989, p. 60; Miller 1956, p. 210; Münch 1994, p. 181), debemos ser cautos al leer los textos coloniales que relatan la aparición del diablo en forma de simio, pues corremos el riesgo de pasar por alto información de corte indígena. Un ejemplo: Fray Gerónimo de Mendieta (2002, I, p. 206) narró que un cacique de Amequemeca le contó a un fraile que en tiempos pasados, « a su padre se le aparecía el demonio en figura de mona a las espaldas sobre el un 


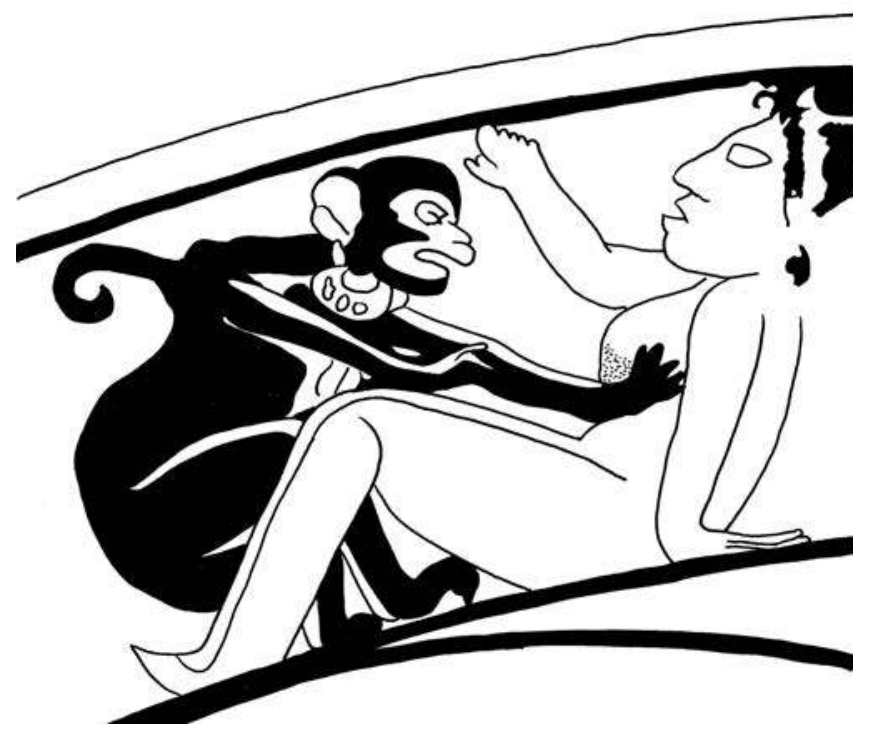

Fig. 9 - Representación de un simio en actitud de cópula con una mujer desnuda en un plato de Uaxactún (dibujo de Jaime Echeverría basado en Smith 1955, II, figura 2g).

hombro, y volviendo a mirarle se le volvía al otro, y así andaba jugando y pasando de una parte a otra ». Al cotejar esta información con un dato asentado por la Histoyre du Mechique (2002 p. 157), se nos revela la identidad divina indígena del « demonio »: se decía que Tezcatlipoca se le aparecía a la gente en figura de simio y les hablaba por sus espaldas ${ }^{19}$. Aunado a esto, tenemos representado al mono con la pintura facial de Tezcatlipoca en la lámina 49 del Borgia.

\section{Seductor, amante y raptor hasta aqui}

El mono, dijeron los informantes nahuas, « bromea a las mujeres jóvenes, continuamente pide algo a la gente, tiende la mano (o el brazo) delante de otros,

19. Se puede afirmar que la aparición diabólica en forma de simio narrada por Mendieta fue retomada de la obra de fray Andrés de Olmos, pues la autoría del texto español original de la Histoyre du Mechique se le ha atribuido a él (De Jonghe 1905, p. 2; Tena, en Mitos e historias... 2002, p. 119), y con seguridad formó parte de su libro sobre las antigüedades de los indios utilizado por Mendieta (2002, I, p. 180; Tena, en Mitos e historias... 2002, p. 119). Sólo que al retomar el franciscano dicha información demonizó al dios indígena. Esta aparición igualmente fue asentada por Olmos (1990, p. 45; véase Baudot 1972, p. 353, 355) en su Tratado de hechicerías y sortilegios: « De igual modo un hombre llamado don Juan, señor de Amecameca, me dijo que antaño, él, a su padre, ya se le había aparecido el hombre-tecolote (el Diablo), parecido a un mono ». Aquí también es evidente la satanización de Tezcatlipoca. 
extiende su mano (o su brazo) ante otros $\gg{ }^{20}$ (quincamanalhuia, in cihuatzitzinti: tetlatlaitlanilia, mamazoa teixpan teixtlan quimamana in ima) (CF, XI, p. 14). Y en palabras de Sahagún (2002, III, p. 997): « cocan a las mujeres; búrlanse con ellas, y demandan de comer, estendiendo la mano, y gritan ». A primera vista, este breve fragmento refleja el carácter juguetón y social del mono, pero mediante el análisis contextual y lingüístico, nos revela la esencia altamente sexual atribuida al mamífero, que era movilizada hacia las mujeres.

Del verbo camanalhuia, utilizado para describir una de las actitudes del simio, fray Alonso de Molina (2004, fol. 12r) da la versión de « enlabiar, dezir gracias, o burlar de palabra »; literalmente, « hacer bromas » (de camanalli, « broma »). Aunque el sentido del término es ampliamente jocoso, su utilización en ciertos contextos también demostró una connotación sexual. Por tal razón, Alex Wimmer (2004, entrada camanalhuia) da como acepción de tecamanalhuia (con el prefijo de objeto indefinido te-) « tentar, seducir a alguien ». Con este sentido lo podemos encontrar en varios pasajes del Códice Florentino. En la fiesta de Uauhquiltamalcualiztli, el ixiptla, o la personificación, de Ixcozauhqui era resguardado por una ahuiani, o mujer de placer, la que le procuraba acciones reconfortantes y placenteras previo a la hora de su muerte: lo alegraba, lo divertía, « lo bromeaba » (quicamanalhuia) (CF, II, p. 169). Tal entretenimiento era con seguridad de carácter sexual. En otra parte, cuando se describe el comportamiento desenfrenado del borracho, se dice que éste « escala muros para seducir y tomar [mujeres] »(tepan tepantemo, tecamanalhuia, tetzitzquia) (CF, IV, p. 13).

Ahora bien, el mono dirigía su actividad bromista y, a la vez, seductora, hacia las cihuatzitzinti, quienes eran las mujeres jóvenes que aún no se habían casado ( $C F$, II, p. 194). No obstante que la acción seductora del simio reflejaba su ámbito de exceso, ésta se encontró delimitada por las reglas sociales, pues sólo era dirigida a las mujeres sexualmente disponibles.

Otra acción del mono también descrita en el Códice Florentino que refleja su falta de control, se expresa mediante el compuesto teixtlan quimana, « la extiende ante otros », refiriéndose a su mano o brazo. Esto se infiere a partir del Vocabulario de Molina, quien da para teixtlan mana la definición de « atrevido en hablar o importuno y moledor » (Molina 2004, fol. 17r).

Esta concepción seductora del simio puede verse reforzada a partir de uno de los elementos presente en una escultura mexica de un mono semi-esculpido sobre una placa en forma de disco, perteneciente al musée du quai Branly (Figura 10, página siguiente). Además de portar ciertos adornos, sostiene entre sus patas y su mano izquierda el tallo de una flor identificada como

20. Traducción propia. Un nombre dado al mono aullador entre los choles es « brazo largo » (Whittaker y Warkentin 1965, p. 57). En varias vasijas mayas se representó al mono con un brazo extendido y la mano abierta hacia arriba, en ocasiones, con semillas de cacao, en actitud de ofrecimiento (véanse en Kerr los vasos K1789 y K9103). 


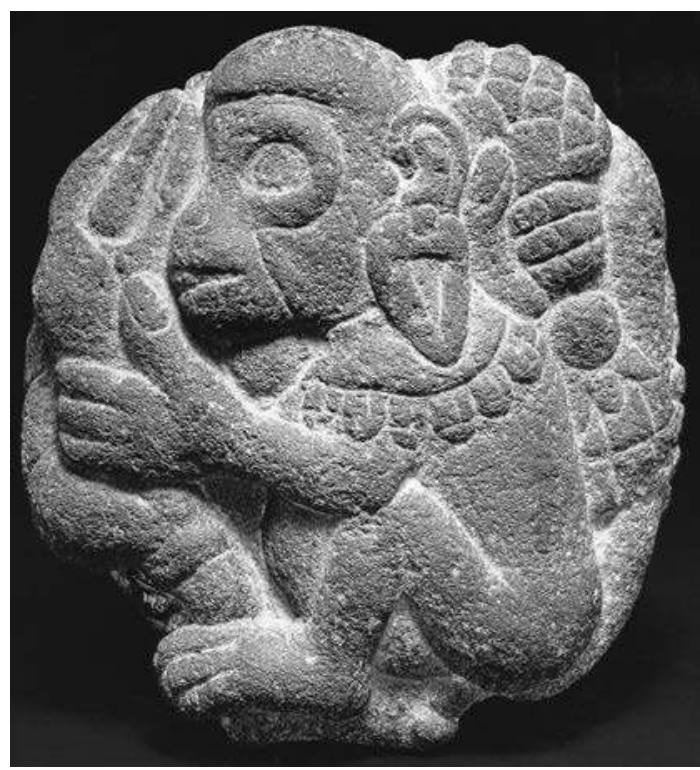

Fig. 10 - Escultura de mono del musée du quai Branly que carga entre sus extremidades el tallo de un alcatraz (López Luján y Fauvet-Berthelot 2005, p. 139, cat. 58).

huacalxochitl por López Luján y Fauvet-Berthelot (2005, p. 138), que corresponde al alcatraz (López Luján y Fauvet-Berthelot en Breuer 2002, p. 424, figura 101). Los cazadores acostumbraban ponerse el fruto de esta flor con su tallo en sus tocados, « para encontrar así caza más abundante y bien dispuesta » (Hernández 1959, II, p. 390). Por otro lado, una variedad de esta flor, la teccizhuacalxochitl, era utilizada por las concubinas de Motecuhzoma Xocoyotzin para procurarse placer ( $C F, \mathrm{XI}$, p. 209). La lógica que posiblemente subyace a esta planta - entre otras -, sugiere Guilhem Olivier (2014, p. 73, 77), es la de que, como entre otros grupos, era utilizada tanto para atraer a las mujeres como para cazar venados, lo que revela la dimensión sexual de la práctica cinegética.

La idea que venimos tratando persiste hasta nuestros días. El simio se percibe entre los otomíes de San Pablito como una « criatura de sexualidad devoradora, es el amante de las mujeres, a quienes hace señas para atraerlas » (Galinier 1990, p. 595). En un cuento narrado por Agustín Bautista, nahua de Zaragoza, Veracruz, se dice que un hombre y su hija fueron a buscar miel al monte. Después de haber llegado a donde estaba el panal y castrarlo, la hija le dijo a su padre que tenía sed, y le indicó que encontraría agua en el tarro de la palma. Beber de dicha agua le ocasionó que quedara embarazada de un mono. Posteriormente en el relato, éste le solicita a su madre que vaya con el rey y le pida en nombre suyo a sus hijas en matrimonio. El rey les presenta la propuesta y sólo acepta la más joven para no contrariar la voluntad paterna. La única condición que él establece es que el simio construya un palacio cuatro veces más grande que el suyo, « para que pueda abrazarla, besarla, morderle los senos a mi hija $\gg{ }^{21}$.

21. Este relato se llama «El cuento del venerable mono » (itapowilis migojtsin), y se trata de una relación oral en náhuatl del citado Agustín Bautista, que fue traducida al español por Antonio García de León. Este cuento está reproducido en un bastidor que cuelga de una de las paredes de la Biblioteca « Rafael García Granados », del Instituto de Investigaciones Históricas de la UNAM, exactamente la que se ubica en el descanso de las escaleras que 
Desconozco a qué se refiera el «tarro de la palma », pero se deduce sin dificultad que el agua contenida en él tenía propiedades fértiles, tanto por el hecho de que la joven resultara embarazada como por el tipo del producto. Entre los antiguos nahuas, los pelos y huesos de simio molidos facilitaban el parto (De la Cruz 1991, fol. 57v, p. 81). El deseo del mamífero de casarse con las hijas del rey nuevamente nos habla de su apetito sexual conducido hacia las mujeres; y no sólo eso, la lubricidad del mono se expresa abiertamente al señalar el relato que le morderá los senos a su prometida. Esto me recuerda una escena pintada en un fragmento de un plato de Uaxactún (fase Tepeu II) en la que se representa a un simio en actitud de cópula con una mujer desnuda, a la que también le acaricia un seno (Smith 1955, II, figura 2g) (Figura 9).

En algunas descripciones etnográficas, la seducción se torna más bien rapto. Unos de los personajes que aparecen en el Carnaval de Chamula son los mašetik, « monos », quienes parodian los movimientos y actitudes de estos mamíferos; además, « amenazan en broma capturar a la gente, enrollarla con la cola y llevársela al bosque ». El siguiente enunciado fue emitido por un mono en un momento de la fiesta: "Cuídense, muchachas; si no me las voy a llevar a mi casa » (Bricker 1986, p. 92, 94-95). Junto con los personajes de negros y judíos - entre otros -, los monos representan el caos primigenio que se reactualiza en cada fiesta de Carnaval, de manera que encarnan el comportamiento desinhibido profundamente antisocial, bien ejemplificado en la obscenidad (Bricker 1986, p. 75, 122; Gossen 1989, p. 60).

Un fragmento de un mito teenek narra que una mujer salió de su casa y vio un gran árbol de zapotes. Mientras recogía los frutos que caían, un mono que estaba en el árbol la sujetó inesperadamente y se la llevó a una cueva. En el medio año que estuvo ahí, dio a luz a monos tras dos meses de embarazo, y en seis meses alumbró tres veces (Ariel de Vidas 2003, p. 220), lo que evidencia la potencia genésica atribuida al mamífero. Por su parte, una versión del relato europeo de Juan Oso narrada en la comunidad nahua de Huitzilan de Serdán, Sierra Norte de Puebla, cuenta al inicio que un hombre trabajaba en su sembradío de maíz y frijol, y cada día su esposa iba a alimentarlo. Ella atravesaba un bosque muy grande que era habitado por animales de la selva. Un día, la mujer partió al atardecer para darle de comer a su esposo, pero en el camino un mono la agarró y se la llevó a una cueva, donde durmió con ella. Ahí concibieron un niño mitad bestia (Taggart 1997, p. 48-49)22.

conducen al Fondo Reservado. Agradezco a Martín Sandoval Cortés, Coordinador de la Biblioteca, por haberme hecho notar la información de este bastidor.

22. Francisco Lugo y Roberto Martínez (2005, p. 235-236, 241, 247) han explicado la sustitución del oso por el simio en las versiones indígenas del cuento de Juan Oso. Primero, la ausencia de plantígrados en regiones como la sierra de Puebla y el sur de Veracruz hizo que el raptor de mujeres cambiara de forma original. Y en la búsqueda de un remplazo autóctono, el mono fue el animal simbólicamente equivalente debido a que ambos mamíferos son 
Atinadamente, Francisco Lugo y Roberto Martínez (2005, p. 243) han relacionado el rapto de mujeres y su consiguiente embarazo en manos del mono con Tezcatlipoca, quien fue el « raptor de mujeres arquetípico » en la cosmovisión nahua prehispánica. Recuerdan que este dios se robó a Xochiquétzal para llevársela al cielo (Muñoz Camargo 1998, p. 166) o al inframundo (Ruiz de Alarcón 1987, p. 154). Y bajo el nombre de Yaotl, Tezcatlipoca también castigó al orgulloso Maxtla, habitante de Toltecatepec, al embarazar a sus dos hijas - celosamente resguardadas - y hacerlas parir a cada una dos creaturas en forma de tlacuache (Anales de Cuauhtitlan 2011, p. 61).

La concepción sexual del mono desborda en el pensamiento indígena. En una narración tzotzil chamula, un mono enroscó su cola alrededor del cuello de un hombre y se lo llevó a su cueva. Su muerte se debió a que varios monos practicaron coito anal con él. Se comieron sus excrementos y lo colgaron de un árbol (Gossen 1989, p. 368-369). A su instinto sexual descontrolado se suma uno de los símbolos claros de la transgresión entre los antiguos nahuas: el excremento. De igual manera, entre los nahuas de Mecayapan, al sur de Veracruz, al simio le da asco la excreta y muere al tocarla (Campos 1982, p. 150).

En la literatura etnográfica también nos encontramos con seres de rasgos humanos y simiescos, que además de tener costumbres semejantes a las de los monos, poseen rasgos físicos particulares que delatan su esencia transgresora. El Mahanamatz o Sisimito de los mayas de Belice es un animal parecido al gorila y de abundante pelo, pero a la vez posee rasgos humanos. También se caracteriza por tener los pies volteados hacia atrás (Thompson 1930, p. 67). Para los chinantecos, el Salvaje es descrito como un animal de grandes dimensiones pero que tiene torso humano y cuenta con una sola pata que, en opinión de algunos, es similar a las extremidades inferiores de los monos. Practica la antropofagia y « ocasionalmente roba mujeres para engendrar en ellas a sus hijos » (Weitlaner 1977, p. 193).

Un defecto en los pies o la ausencia de una de las extremidades inferiores fue una metáfora de la transgresión en Mesoamérica, especialmente de carácter sexual (Códice Vaticano B 1972, lám. 79, p. 147; Relación de Michoacán 1989, p. 133; Olivier 2004, p. 423). Y este mismo sentido expresan los pies invertidos de figuras como el Mahanamatz o la presencia de una sola extremidad. Dicho rasgo puede ser análogo al torcimiento de cualquier otra parte del cuerpo,

pensados como próximos a lo humano (véanse algunas leyendas vascas que enfatizan este pensamiento en Marliave [1995, p. 126]). Y aún más, a semejanza del mono mesoamericano, en las tradiciones orales de los Pirineos el oso mantiene un simbolismo de fecundidad. Se cuenta que en el valle de Barèges, una mujer fue al lago de Ardiden para bañarse con un oso, del que tuvo siete hijos (Marliave 1995, p. 126-127). Para el caso de los pueblos nahuas, la constante sustitución también puede deberse a la proximidad fonética que guardan las palabras oso y ozomatli, «mono » en náhuatl (comunicación personal de Taggart, 2002, a Lugo y Martínez [2005, p. 241]). 
como la cabeza, de tal manera que las formas simiescas documentadas por la etnografía se entrelazan con la imagen del mono de la lámina 32 del Códice Vaticano $B$ (véase Figura 1) aludida en varias ocasiones. Otro elemento que también las une es la asociación de la excreta con el mono, lo que refuerza la naturaleza sexual transgresora del mamífero ${ }^{23}$.

Las escenas simiescas de seducción, rapto e hipersexualidad, se prestan a una lectura que parte desde las esferas mental - especialmente desde lo inconsciente y social. El mono simboliza el deseo sexual no constreñido por la cultura. En aquél se ha depositado el deseo inconsciente masculino de poseer a todas las mujeres, ya sea por medio de la seducción, o incluso la fuerza, lo que permite aflorar las pulsiones agresivas masculinas. Mediante la construcción imaginaria del mono, la potencia viril no es desviada hacia los fines sociales esperados, sino que mantiene el curso dictado por el instinto, caracterizado por el salvajismo, la desmesura y la satisfacción narcisista. El hombre salvaje sepultado en el inconsciente por el proceso civilizatorio aflora mediante figuras bestiales cercanas a lo humano, que no por ello dejan de pertenecer a la naturaleza.

En el ámbito social, el comportamiento sexual señalado para el simio puede mantener una correspondencia con las maneras de que disponen los hombres para obtener mujeres. Planteo lo siguiente a manera de hipótesis. La vía que no afecta el orden comunitario, y que implica el consentimiento de las mujeres, es la seducción, la cual involucra una capacidad verbal de persuasión que permite a los hombres entablar amoríos con ellas. A esta capacidad remite el verbo tecamanalhuia comentado al inicio del apartado, que refiere a un lenguaje jocoso y sexual con miras a lograr una conquista amorosa. La otra forma de poseer mujeres, mucho menos cuidada que la anterior y con repercusiones sociales importantes, es el rapto y la posterior violación. Esta puede presentarse en dos contextos: 1. como resultado de una frustración ante el rechazo de la actividad seductora; y 2. por una falla en los mecanismos de contención de la conducta que deja rienda suelta al disfrute del sexo por la vía violenta. El tema del mono raptor de mujeres da la nota bestial al acto de la violación, lo que indica la gravedad de la falta. Así, la violación se vuelve un acto deshumanizado.

\section{Exceso y deshumanización}

Quiero finalizar este texto con la exposición de la idea de que el comportamiento excesivo atentaba contra la identidad humana, al grado de provocar en el hombre un estado deshumanizado. En términos simbólicos, esta deshumanización denotaba el estado de inmoralidad en que vivía la persona. En el ámbito del mito, la acción transgresora era con frecuencia castigada con la mutación animal. Por

23. Recordemos que la figura del mono de la lámina 32 del Vaticano $B$, se caracteriza por tener rotada la cabeza hacia atrás y estar expulsando un chorro de excremento. 
falta de espacio, no he considerado en este apartado los numerosos y variados ejemplos míticos provistos por la etnografía, que versan sobre la transformación de los sobrevivientes del diluvio en mono a causa de sus transgresiones.

El comportamiento inmoral ocurría una vez que la persona transgredía los límites de la moderación; de esta manera, toda acción humana contraventora era considerada un exceso: exceso del habla, exceso del comer, exceso de la actividad sexual, etcétera. Las acciones humanas transgresoras, especialmente las de carácter sexual, o que tenían una repercusión en el ámbito de la sexualidad, se encontraban bajo el influjo del exceso promovido por los dioses Xochipilli y Macuilxóchitl y los símbolos que precedían. Como ya se había adelantado, el número cinco (macuilli) era un aspecto esencial de la identidad de éste. Para los nahuas, dicho numeral fue considerado el símbolo de la desmesura por antonomasia. Este dígito, por ejemplo, determinó la cantidad de tazas de pulque que provocaba la embriaguez, la cual desinhibía el comportamiento a tal grado de llevar a la desnudez o incluso a cometer incesto (CF, X, p. 193; Anales de Cuauhtitlan 2011, p. 47). La concepción que se tenía del número cinco y, por lo tanto, del exceso, está fielmente expresada en el Códice Florentino $(C F, \mathrm{IV}$, p. 71). Se decía que:

[...in izquican tlamacuiltilia tonalli, mochi amo cualli: in aquique oncan tlacati, amo tlacacemelleque, amo tlaca, tlahueliloque... inin icuac tlacat ic tenmachoc in itonal macuilli: quitlamauhcaittilique, quitlatenmachilique].

...todos los signos de día que ocupaban la quinta posición eran malos: quienes allí nacían eran perversos, no humanos, malvados... Cuando nacía se experimentaba la angustia con su tonalli [de número] cinco: lo veían con miedo, les angustiaba ${ }^{24}$

Al estar poseída por el número cinco, ya fuera por su signo de día o por un comportamiento transgresor, la persona era dominada por un impulso excesivo que la hacía despojarse de las imposiciones culturales, de tal manera que devenía en un amotlacatl, « no humano ». Este concepto refería al inhumano, cruel y perverso (Siméon 2002, p. 556, 561; López Austin 1996, I, p. 203), el cual contrasta de forma rotunda con los vocablos tlacatl y tlacayotl, « humano » y « humanidad », respectivamente, cuyo campo semántico abarcaba la bondad, lo pacífico, lo afable, la generosidad y la compasión (Siméon 2002, p. 556, 561; López Austin 1996, I, p. 203). El comportamiento transgresor y excesivo, que hacía del hombre un ser perverso, borraba los rasgos típicamente humanos para dar paso a la deshumanización.

Tomo como punto de partida el pasaje en el que Cuextécatl se embriaga para ejemplificar lo que acabo de comentar. Una vez que los dioses del pulque prepararon la bebida, invitaron a todos los dirigentes y ancianos, y entre ellos estaba presente Cuextécatl. Les ofrecieron comida y pulque; cada uno tomó

24. Traducción propia. 
cuatro tazas, pero aquél tomó cinco. Esta acción le provocó un inmediato estado de ebriedad que le hizo arrojar su maxtlatl, o calzoncillo, en frente de la gente. Avergonzado, decidió abandonar la tierra y se llevó consigo a su linaje, los cuextecas o huastecos ( $C F, \mathrm{X}, \mathrm{p}$. 193).

La deshumanización de Cuextécatl nos es conocida a partir de la esencia del numeral cinco, señalado en la cantidad de tazas de pulque ingeridas, y del consiguiente estado de embriaguez que lo posee. Se decía del borracho que « él no lo toma [el pulque] de manera humana, lo desea con exceso » (aquimotlacamaca, quitlaelnequi) (CF, IV, p. 11). Y en otra parte del Códice Florentino se señala: « Ahí está su palabra, no salida de boca humana » (Iz ca atlacaquiza in iten in itlatol) (Sahagún 1995, p. 112, 123).

Además de proporcionar la explicación mexica de la naturaleza incontinente del cuexteca, el tema de la desnudez de la narración anterior es un elemento que enfatiza la salvajización de la persona, pues corresponde al ámbito bestial. En una parte del mito quiché de los gemelos Hunbatz y Hunchohuén del Popol Vuh, se observa la materialización de la deshumanización, la que, siguiendo un orden lógico, podría habérsele aplicado a Cuextécatl. Se cuenta que mediante engaños, los gemelos Hunahpú e Ixbalanqué hicieron que Hunbatz y Hunchohuén, sus hermanos mayores, se subieran al árbol Canté para bajar los pájaros que no caían al suelo. Al no poder descender, Hunahpú e Ixbalanqué les dijeron que se desataran sus calzoncillos. En el instante que lo hicieron, éstos se convirtieron en colas y tomaron la apariencia de monos. Y así, se internaron en el bosque haciendo gestos y movimientos simiescos (Popol Vuh 2005, p. 66-67). Posteriormente se dice que fueron convertidos en monos porque se ensoberbecieron y maltrataron a sus hermanos (Popol Vuh 2005, p. 69).

Me interesa el anterior relato quiché porque nos habla de la transformación en mono como consecuencia de actos inmorales. Esta idea igualmente persiste en una de las narraciones nahuas de la destrucción del mundo por el viento. Muy posiblemente también tengamos un ejemplo escultórico mexica, en el que se dispuso del recurso de la animalización para representar una acción contraria a los cánones plásticos dictados, en parte, por el pudor y las buenas costumbres mexicas. Me refiero a la imagen de una pareja con rasgos humanos y simiescos sentada en una banca, que se ve de frente y se abraza (Figura 11, página siguiente). Esta escultura es muy singular por ser la única pareja y la única manifestación de afecto representadas en el arte mexica. A partir de la propuesta de que esta imagen corresponde a la del acto sexual (Mena 1926, citado por Solís 1985, p. 426), Felipe Solís (1985, p. 426) hizo un comentario muy sugerente respecto a dicha escultura:

La manifestación del acto sexual no era un motivo popular de representación artística; cuando se plasma, siempre tiene por objeto asociarlo con la idea de fecundidad, tanto de la tierra como de los individuos; esta puede ser la razón por la cual las figuras lucen rasgos faciales de simios, deshumanizando en cierta 


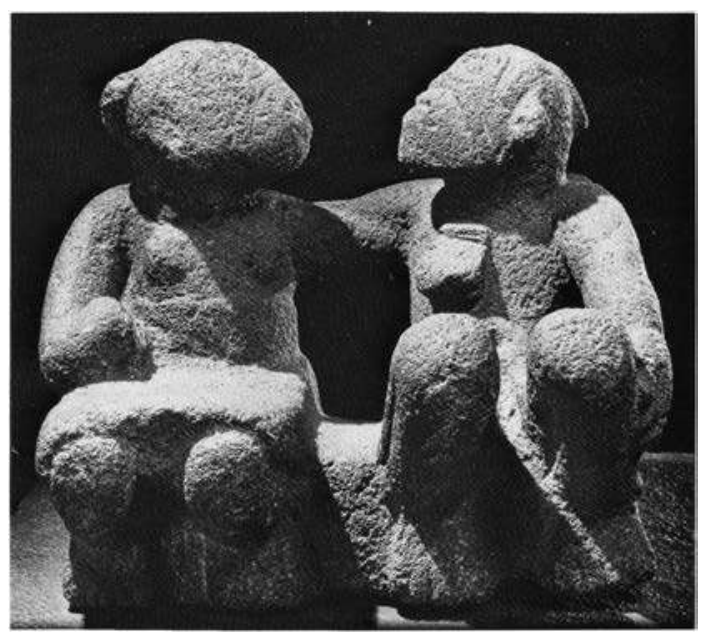

Fig. 11 - Pareja con rasgos simiescos que se abraza, sentada en una banca. Museo Nacional de Antropología, Sala Mexica (Pasztory 1983, p. 232). medida la representación y dando a la pareja el carácter lúbrico que caracteriza a estos animales, evitando que dicho acto presentado al público fuera contemplado como motivo de regocijo.

$\mathrm{Su}$ posición intermedia entre los ámbitos bestial y humano, sus atribuciones sexuales y, de manera importante, su naturaleza excesiva, fueron motivos determinantes para que algunos pueblos prehispánicos efectuaran la deshumanización de la persona transgresora en la figura del mono. En este sentido, dicho mamífero « fungió como depositario de conductas humanas reprimidas » (Echeverría 2012, p. 175).

\section{Reflexiones}

El mono es un animal de contradicciones, a veces difíciles de dilucidar. Encarnaba los valores de vida y fertilidad pero a la vez poseía un significado de muerte. Mientras sus signos de día eran auspiciosos, su naturaleza era esencialmente transgresora. En términos sencillos, el simio simbolizó el exceso de lo que era bueno en sí mismo, lo cual nos remite al principio moral básico nahua: la conducción del comportamiento dirigido por el punto medio. Paralelamente, la condición del ser humano era fundamentalmente buena, pero los apetitos inmoderados la orillaban a la maldad. El simio, entonces, se concibió como un reflejo distorsionado del ser humano: extremadamente semejante a él pero siempre imperfecto al comparársele. Esta imperfección no sólo repercutía en el aspecto físico, también en el comportamental. Si en el hombre, como se dijo, albergaba la bondad y la rectitud, el mono las deformaba.

La figura del simio, podemos decir, fue moralizante. Mostraba el destino de aquellas personas que en el pasado se habían dejado guiar por sus impulsos: la deshumanización, y que también podía ocurrir en el tiempo presente. Un pensamiento indígena generalizado es que el comportamiento inmoral ocasiona la transformación en bestia. La forma simiesca es particularmente apta para representarla, pues muestra los signos de la degradación de la condición humana. Vivir bajo el imperio de los instintos aleja al hombre de la ley, del orden de la cultura, esto es, de lo meramente humano. Bajo una forma animal no puede habitarse más en la ciudad, ahora el ser bestializado debe replegarse a la periferia salvaje y hacer habitación en el bosque o en la cueva, siendo ésta 
un lugar privilegiado de morada para los monos o los personajes simiescos de los relatos indígenas.

Las interacciones y desplazamientos que se establecen entre los seres humanos y los animales son variadas y complejas. Las que destacan de manera importante en el pensamiento mesoamericano están contenidas en los fenómenos del « tonalismo » y del « nahualismo ». El tonalismo refiere a la relación de co-esencia que se establece entre el ser humano y su animal compañero; mientras que el nahualismo consiste en la creencia de que determinados individuos, particularmente dotados y poderosos, poseen la capacidad de transformarse en animales (véase Lupo en prensa) ${ }^{25}$. En este artículo me centré en un tipo diferente de relación, que consiste en que el elemento bestial del hombre debe ser rechazado para que la verdadera esencia humana, en conjunción con la cultura, pueda aflorar. Pero ese rechazo no implica su aniquilación, la parte bestial es sepultada por el orden de la cultura y alojada en el inconsciente; y ahí permanece, latente. Las acciones transgresoras del hombre atentan directamente contra su humanidad, esto permite que lo animal interior se vuelva manifiesto. Este movimiento de lo humano a lo animal no es un hecho sujeto a la voluntad del hombre - por lo menos en el mito -, sino que es efectuado por la divinidad encolerizada: la falta se castiga con la pérdida de humanidad.

Un aspecto fundamental que revela el simio es que la noción de humanidad no puede concebirse aislada de la idea del salvajismo. En un sentido evolutivo, para alcanzar la humanidad, emparejada con la civilización, se debe de transitar previamente por un estado salvaje. Y sólo con la adquisición de determinados signos materiales - e inmateriales - de cultura es posible adoptar de manera definitiva la condición de ser humano. Sin embargo, dicha condición no es inmutable. El comportamiento antisocial puede ocasionar un retorno a los orígenes salvajes, a la animalización. Y justamente allí radica uno de los miedos más profundos del hombre civilizado. *

* Manuscrit reçu en juin 2013, accepté pour publication en avril 2015.

Agradezco a la Coordinación de Humanidades de la Universidad Nacional Autónoma de México por haberme otorgado una beca de investigación, por parte del Programa de Becas Posdoctorales en la Unam, la cual me permitió elaborar este artículo. También agradezco a Guilhem Olivier por la atenta lectura del texto y sus comentarios.

25. Esta idea de nahualismo es la más generalizada y, en opinión de algunos, la más simplista (López Austin 1996, II, p. 422). Para López Austin (ibid., p. 429), el nahualismo « es un tipo de toma de posesión que realizan hombres, dioses, muertos y animales, remitiendo una de sus entidades anímicas, el ihiyotl o nahualli, para que quede cubierto dentro de diversos seres, entre los que predominan animales... » En el mismo sentido, en su extenso y detallado estudio sobre el nahualismo, Martínez González (2011, p. 144) afirma que « la "transformación" del nahualli es un acto que no implica ninguna modificación corporal », sino que refiere al hecho de « poder controlar las deambulaciones de su entidad compañera durante los sueños por medio de la transferencia del tonalli humano al cuerpo de su coesencia ». 


\section{Referencias citadas}

\section{Abreviaturas}

$\begin{array}{ll}\text { ADV } & \text { Akademische Druck-und Verlagsanstalt } \\ \text { CEMCA } & \text { Centro de Estudios Mexicanos y Centroamericanos } \\ \text { CF } & \text { Véase Sahagún, Florentine Codex } \\ \text { CM } & \text { El Colegio de México } \\ \text { CIESAS } & \text { Centro de Investigaciones y Estudios Superiores en Antropología Social } \\ \text { COLSAN } & \text { El Colegio de San Luis } \\ \text { CONACULTA } & \text { Consejo Nacional para la Cultura y las Artes } \\ \text { FCE } & \text { Fondo de Cultura Económica } \\ \text { FFyL } & \text { Facultad de Filosofía y Letras, UnAm } \\ \text { IIA } & \text { Instituto de Investigaciones Antropológicas, UnAM } \\ \text { IIF } & \text { Instituto de Investigaciones Filológicas, UnAM } \\ \text { IIH } & \text { Instituto de Investigaciones Históricas, UNAM } \\ \text { IMSS } & \text { Instituto Mexicano del Seguro Social } \\ \text { INAH } & \text { Instituto Nacional de Antropología e Historia } \\ \text { INI } & \text { Instituto Nacional Indigenista } \\ \text { IRD } & \text { Instituto de Investigación para el Desarrollo } \\ \text { SEP } & \text { Secretaría de Educación Pública } \\ \text { SHCP } & \text { Secretaría de Hacienda y Crédito Público } \\ \text { UNAM } & \text { Universidad Nacional Autónoma de México }\end{array}$

Alva IxTLiLXochitl Fernando de

1997, Obras históricas, Edmundo O'Gorman (ed.), Instituto Mexiquense de Cultura/ Unam, IIH, México, 2 vols.

\section{Anales de Cuauhtitlan}

2011, Edición y traducción de Rafael Tena, Conaculta (Cien de México), México.

ArIEL DE VIDAs Anath

2003, El trueno ya no vive aquí. Representación de la marginalidad teenek (Huasteca veracruzana, México), traducción de Ari Zighelboim, Ciesas/Cemca/Colsan/ IRD, México.

\section{BAUDOT Georges}

1972, « Apariciones diabólicas en un texto náhuatl de fray Andrés de Olmos », Estudios de cultura náhuatl, 10, p. 349-357.

Benavente fray Toribio de

1996, Memoriales (Libro de oro, MS JGI 31), Nancy Joe Dyer (ed.), CM/Centro de Estudios Lingüísticos y Literarios (Biblioteca Novohispana, 3), México.

2007, Historia de los indios de Nueva España, Edmundo O'Gorman (ed.), Editorial Porrúa (Sepan cuantos..., 129), México.

BREUER David et al. (eds.)

2002, Aztecs, Royal Academy of Arts, Londres. 
BRICKER Victoria Reifler

1986, Humor ritual en la altiplanicie de Chiapas, traducción de Judith Sabines Rodríguez, FCE, México.

BurkHART Louise M.

1986, « Moral deviance in sixteenth-century Nahua and christian thought: the rabbit and the deer », Journal of Latin American lore, 12 (2), p. 107-139.

CAmpos Julieta

1982, La herencia obstinada. Análisis de cuentos nahuas, FCE, México.

$C F$, véase SAHAGÚN 1950-1981

CAROCHI Horacio

1983, Arte de la lengua mexicana. Con la declaración de los adverbios della, Miguel León Portilla (ed.), UNAM, IIF, IIH (Facsímiles de Lingüística y Filología Nahuas, 2), México.

(Códice Borgia) Codex Borgia

2008, Biblioteca Apostólica Vaticana/Testimonio Compañía Editorial, Madrid.

Códice Telleriano-Remensis

1964, Antigüedades de México, basadas en la recopilación de Lord Kingsborough, José Corona Núñez (ed.), SHCP, México, vol. I, p. 151-337.

Codex Telleriano-Remensis

1995, Codex Telleriano-Remensis: ritual, divination, and history in a pictorial Aztec manuscript, Eloise Quiñones Keber (ed.), University of Texas Press, Austin.

(Códice Vaticano A) Códice Vaticano 3738

1964, Antigüedades de México, basadas en la recopilación de Lord Kingsborough, José Corona Núñez (ed.), SHCP, México, vol. III, p. 1-314.

(Códice Vaticano B) Codex Vaticanus 3773

1972, Biblioteca Apostolica Vaticana, Ferdinan Anders (ed.), ADV, Graz.

Chimalpain Cuauhtlehuanitzin Domingo Francisco de San Antón Muñón

1997, Primer amoxtli libro. $3^{a}$ relación de las Différentes histoires originales, Víctor M. Castillo Farreras (ed.), UnAm, IIH (Serie Cultura Náhuatl, Fuentes, 10), México.

DAviEs Nigel

1977, The Toltecs. Until the fall of Tula, University of Oklahoma Press, Norman.

De La CRUZ Martín

1991, Libellus de medicinalibus indorum herbis, manuscrito azteca de 1552 según traducción latina de Juan Badiano, versión española con estudios y comentarios por diversos autores, FCE/IMSS, México.

De Jonghe M. Édouard

1905, « Histoyre du Mechique, manuscrit français inédit du XVI ${ }^{\mathrm{e}}$ siècle », Journal de la société des américanistes, 2, p. 1-41.

DURÁn fray Diego

2002, Historia de las Indias de Nueva España e islas de tierra firme, Rosa Camelo y José Rubén Romero (eds.), Conaculta (Cien de México), México, 2 tomos. 
ECHEVERRÍA GARCÍA Jaime

2012, Los locos de ayer. Enfermedad y desviación en el México antiguo, Instituto Mexiquense de Cultura (Biblioteca de los pueblos indígenas), México.

(en prensa), « Entre la fertilidad agrícola y la generación humana: el rol fecundante del mono entre los antiguos nahuas », Estudios de cultura náhuatl, 50.

ELIAS Norbert

2009, El proceso de la civilización. Investigaciones sociogenéticas y psicogenéticas, traducción de Ramón García Cotarelo, FCE, México.

Escalante Gonzalbo Pablo

2010, Los códices mesoamericanos antes y después de la conquista española. Historia de un lenguaje pictográfico, FCE, México.

Fernández De Oviedo y Valdés Gonzalo

1944-1945, Historia general y natural de las Indias, islas y Tierra-Firme del Mar Océano, t. XI, José Amador de los Ríos (ed.), Editorial Guaranía, Asunción.

Foster George M.

1945, Sierra Popoluca folklore and beliefs, University of California Press (University of California Publications in American Archaeology and Ethnology, 42-2), Berkeley.

FREUd Sigmund

2000, « Tótem y tabú. Algunas concordancias en la vida anímica de los salvajes y de los neuróticos (1913 [1912-13]) », in Obras completas, vol. XIII, Tótem y tabú y otras obras (1913-1914), Amorrortu editores, Buenos Aires, p. 1-164.

2003, « Lo inconciente (1915) », in Obras completas, vol. XIV, Contribución a la historia del movimiento psicoanalítico. Trabajos sobre metapsicología y otras obras (1914-1916), Amorrortu editores, Buenos Aires, p. 153-213.

GALINIER Jacques

1990, La mitad del mundo. Cuerpo y cosmos en los rituales otomíes, traducción de Ángela Ochoa y Haydée Silva, UnAm/CEMCA/INI, México.

GARCía quintana Josefina

1974, " Exhortación de un padre a su hijo. Texto recogido por Andrés de Olmos », Estudios de cultura náhuatl, 11, p. 137-182.

Gossen Gary H.

1989, Los chamulas en el mundo del sol. Tiempo y espacio en una tradición oral maya, traducción de Celia Paschero, Conaculta/INI, México.

Graulich Michel

1990, Mitos y rituales del México antiguo, traducción de Ángel Barral Gómez, Colegio Universitario de Ediciones Istmo, Madrid.

HERNÁNDEZ Francisco

1959, Obras completas. Historia natural de la Nueva España, t. 2-3, vols. 1-2, UnAm, México.

1986, Antigüedades de la Nueva España, Ascensión H. de León-Portilla (ed.), Historia 16, Madrid. 
Historia de los mexicanos por sus pinturas

2002, Mitos e historias de los antiguos nahuas, Rafael Tena Martínez (ed.), Conaculta (Cien de México), México, p. 23-95.

Historia Tolteca-Chichimeca

1989, Edición y traducción de Paul Kirchoff, Lina Odena Güemes y Luis Reyes García, Ciesas/FCE/Gobierno del Estado de Puebla, México.

Histoyre du Mechique

2002, Mitos e historias de los antiguos nahuas, edición y traducción de Rafael Tena Martínez, Conaculta (Cien de México), México, p. 123-165.

Houston Stephen D.

2001, « Decorous bodies and disordered passions: representations of emotion among the Classic Maya », World archaeology, 33 (2), p. 206-219.

KERR Justin

Maya vase data base. An archive of rollout photographs, http://research.mayavase. com/kerrmaya.html, consultado el día 5 de mayo de 2013.

KLEIN Cecelia F.

2001, « None of the above: gender ambiguity in Nahua ideology », in Cecelia F. Klein (ed.), Gender in prehispanic America, Dumbarton Oaks, p. 183-253.

LeÓN-Portilla Miguel

1967, « El proceso de aculturación de los chichimecas de Xólotl », Estudios de cultura náhuatl, 7, p. 59-86.

Leyenda de los Soles

2002, In Mitos e historias de los antiguos nahuas, edición y traducción de Rafael Tena Martínez, Conaculta (Cien de México), México, p. 173-205.

LÓPEz Austin Alfredo

1996, Cuerpo humano e ideología. Las concepciones de los antiguos nahuas, UnAM, IIA, México, 2 tomos.

LóPEZ Austin Alfredo y Leonardo LóPEZ LujáN

1999, Mito y realidad de Zuyuá. Serpiente emplumada y las transformaciones mesoamericanas del Clásico al Posclásico, CM/Fideicomiso Historia de las Américas/ FCE, México.

LóPez LujÁn Leonardo y Marie-France Fauvet-Berthelot

2005, Aztèques. La collection de sculptures du musée du quai Branly, Musée du quai Branly, Paris.

Lugo Silva Francisco y Roberto Martínez GonzÁlez

2005, « Juan Oso y la paradoja del sincretismo en Mesoamérica », Anales de antropología, 39 (2), p. 231-253.

LuPo Alessandro

(en prensa), « Entre venados y lagartas. Roles, valores e identidades en las narraciones huaves sobre el sexo entre animales y humanos ", Itinerarios, 21. 
Marliave Olivier de

1995, Pequeño diccionario de mitología vasca y pirenaica, traducción de Esteve Serra, José J. de Olañeta (Alejandría, 6), Palma de Mallorca.

Martínez GonZÁLEz Roberto

2011, El nahualismo, UnAm/IIH/IIA, México.

Mena Ramón

1926, Catálogo del salón secreto (culto al falo), Museo Nacional de Arqueología, Historia y Etnografía, México.

Mendieta fray Gerónimo de

2002, Historia eclesiástica indiana, Antonio Rubial García (ed.), Conaculta (Cien de México), México, 2 tomos.

MiLler Walter S.

1956, Cuentos mixes, INI, México.

Miller Mary y Karl TAube

1993, The gods and symbols of Ancient Mexico and the Maya. An illustrated dictionary of Mesoamerican religion, Thames and Hudson, Londres.

Molina fray Alonso de

2004, Vocabulario en lengua castellana y mexicana y mexicana y castellana, Miguel León-Portilla (ed.), Editorial Porrúa, México.

Moreno De Los Arcos Roberto

1967, « Los cinco soles cosmogónicos », Estudios de cultura náhuatl, 7, p. 183-210.

Munch GaLindo Guido

1994, Etnología del istmo veracruzano, UnAm, IIA, México.

Muñoz CAmargo Diego

1998, Historia de Tlaxcala (Ms. 210 de la Biblioteca Nacional de París), Luis Reyes García (ed.), con la colaboración de Javier Lira Toledo, Gobierno del Estado de Tlaxcala/Ciesas/Universidad Autónoma de Tlaxcala, Tlaxcala.

NÁJera Coronado Martha Ilia

2000, « Cambios y permanencias en la religión maya a través del análisis del significado de la figura simbólica del mono », Estudios mesoamericanos, 2, julio-diciembre, p. 49-56.

2008, « El rito del "palo volador": encuentro de significados », Revista española de antropología americana, 381, p. 51-73.

2012, « El mono y el cacao: la búsqueda de un mito a través de los relieves del grupo de la serie inicial de Chichén Itzá », Estudios de cultura maya, 39, p. 133-172.

Navarrete Linares Federico

2011a, Los orígenes de los pueblos indígenas del valle de México. Los altépetl y sus historias, UNAM, IIH, México.

2011b, «Chichimecas y toltecas en el valle de México », Estudios de cultura náhuatl, 42, p. 19-50. 
Nicholson Henry B.

1975, «Religion in Pre-Hispanic Central Mexico », in Gordon F. Ekholm, Ignacio Bernal e Robert Wauchope (eds.), Handbook of Middle American Indians, vol. 10, Archaeology of Northern Mesoamerica, parte 1, University of Texas Press, Austin, p. 395-446.

OLIVIER Guilhem

2004, Tezcatlipoca. Burlas y metamorfosis de un dios azteca, traducción de Tatiana Sule, FCE, México.

2014, « Venados melómanos y cazadores lúbricos: cacería, música y erotismo en Mesoamérica », Estudios de cultura náhuatl, 47, enero-junio, p. 71-118.

Olmos fray Andrés de

1990, Tratado de hechicerías y sortilegios, Georges Baudot (ed.), UnAm, IIH/CEMCA, México.

PASZTORY Esther

1983, Aztec art, University of Oklahoma Press, Singapur.

Penagos Belman Esperanza

2000, « El consumo del maíz en la construcción de la persona mazateca », Cuicuilco, 7-8, enero-abril, p. 1-8.

PETRICH Perla

1985, La alimentación mochó: acto y palabra (estudio etnolingüístico), Universidad Autónoma de Chiapas, Centro de Estudios Indígenas, San Cristóbal de las Casas.

Popol Vuh

2005, Edición y traducción de Adrián Recinos, FCE (Colección Popular, 11), México.

Ramos De CÁRdenas Francisco

1987, « Relación de Querétaro », in René Acuña (ed.), Relaciones geográficas del siglo xvi: Michoacán, vol. 9, UnAm, IIA, México, p. 206-248.

Relación de Michoacán

1989, Leoncio Cabrero (ed.), Historia 16 (Crónicas de América, 52), Madrid.

Reyes García Luis y Lina Odena Güemes

2001, « La zona del Altiplano central en el Posclásico: la etapa chichimeca », in Linda Manzanilla y Leonardo López Luján (coords.), Historia antigua de México, vol. III, El horizonte Posclásico, InAH/UnAm/Editorial Porrúa, México, p. 237-276.

Ruiz de Alarcón Hernando

1987, « Tratado de supersticiones y costumbres gentílicas que hoy viven entre los indios naturales desta Nueva España », in Fernando Benítez (ed.), El alma encantada, INI/FCE, México, p. 123-223.

SAHAGÚN fray Bernardino de

1950-1981, Florentine Codex. General History of the things of New Spain, Fray Bernardino de Sahagún, edición y traducción de Charles E. Dibble y Arthur J. O. Anderson, School of American Research/University of Utah, Santa Fé.

1995, Los once discursos sobre la realeza. Libro sexto del Códice Florentino, edición y traducción de Salvador Díaz Cíntora, Unam, México.

1997, Primeros Memoriales, edición y traducción de Thelma Sullivan, revisión de Henry B. Nicholson, University of Oklahoma, Norman. 
SAHAGún fray Bernardino de (suite)

2002, Historia general de las cosas de Nueva España, Alfredo López Austin y Josefina García Quintana (eds.), Conaculta (Cien de México), México, 3 tomos.

SIMÉON Rémi

2002, Diccionario de la lengua náhuatl o mexicana, traducción de Josefina Oliva de Coll, Siglo veintiuno ed., México.

SELER Eduard

1980, Comentarios al Códice Borgia, traducción de Mariana Frenk, FCE, México, 2 tomos.

2004, Las imágenes de animales en los manuscritos mexicanos y mayas, Brígida von Mentz (ed.), traducción de Joachim von Mentz, Casa Juan Pablos, México.

Sмiтн Robert E.

1955, Ceramic sequence at Uaxactun, Guatemala, Middle American Research Institute, Tulane University (Publication, 20)/Carnegie Institution of Washington, Nueva Orleans, vol. II (Ilustrations).

Solís Olguín Felipe

1985, « Arte, Estado y sociedad. La escultura antropomorfa de México-Tenochtitlan », in Jesús Monjarás-Ruiz, Rosa Brambila y Emma Pérez-Rocha (recops.), Mesoamérica y el centro de México, InaH, México, p. 393-432.

TAGgart James M.

1997, The bear and his sons. Masculinity in Spanish and Mexican folktales, University of Texas Press, Austin.

Thompson J. Eric

1930, Ethnology of the Mayas of Southern and Central British Honduras, Field Museum of Natural History, Chicago.

Veytia Mariano

2000, Historia antigua de México, Editorial del Valle de México, México, 2 tomos.

WeitLANER Roberto J.

1977, Relatos, mitos y leyendas de la Chinantla, María Sara Molinari, María Luisa Acevedo y Marlene Aguayo Alfaro (eds.), INI, México.

WhitTAKer Arabelle y Viola WARKENTIN

1965, Chol texts on the supernatural, Summer Institute of Linguistics of the University of Oklahoma, México.

Wimmer Alexis

2009, «Diccionario de náhuatl clásico », in GDN. Gran diccionario del náhuatl, en CEN. Compendio Enciclopédico del Náhuatl, InAH, México, DVD-ROM [2004].

XIMÉNEZ fray Francisco

2001, Cuatro libros de la naturaleza y virtudes de las plantas y animales, de uso medicinal en la Nueva España, facsímil de la edición mexicana de 1888, Biblioteca Mexicana de la Fundación Miguel Alemán, México. 